\title{
Diversification, Intensification and Specialization: Changing Land Use in Western Africa from 1800 BC to AD 1500
}

\author{
Andrea U. Kay, et al. [full author details at the end of the article]
}

Published online: 16 May 2019

(c) The Author(s) 2019

\begin{abstract}
Many societal and environmental changes occurred between the 2nd millennium BC and the middle of the 2nd millennium AD in western Africa. Key amongst these were changes in land use due to the spread and development of agricultural strategies, which may have had widespread consequences for the climate, hydrology, biodiversity, and ecosystem services of the region. Quantification of these land-use influences and potential feedbacks between human and natural systems is controversial, however, in part because the archaeological and historical record is highly fragmented in time and space. To improve our understanding of how humans contributed to the development of African landscapes, we developed an atlas of landuse practices in western Africa for nine time-windows over the period $1800 \mathrm{BC}-\mathrm{AD}$ 1500. The maps are based on a broad synthesis of archaeological, archaeobotanical, archaeozoological, historical, linguistic, genetic, and ethnographic data, and present land use in 12 basic categories. The main differences between categories is the relative reliance on, and variety of, domesticated plant and animal species utilized, and the energy invested in cultivating or keeping them. The maps highlight the irregular and frequently non-linear trajectory of land-use change in the prehistory of western Africa. Representing an original attempt to produce rigorous spatial synthesis from diverse sources, the atlas will be useful for a range of studies of human-environment interactions in the past, and highlight major spatial and temporal gaps in data that may guide future field studies.
\end{abstract}

Keywords Archaeology · Land-use change · Western Africa · Human subsistence · Iron age $\cdot$ Archaeobotany $\cdot$ Archaeozoology $\cdot$ Agriculture

Electronic supplementary material The online version of this article (https://doi.org/10.1007/s1096 3-019-09131-2) contains supplementary material, which is available to authorized users.

Andrea U. Kay

kay@shh.mpg.de 


\section{Introduction}

In sub-Saharan Africa over the last four millennia, the types of societal shifts that either occurred in response to environmental change or that acted as drivers of that change include the shift to food production, the development of iron metallurgy, population growth, and the emergence of centralized states and empires. Additionally, different societies had different means of maintaining their way of life, and these livelihoods had varying effects on their local environments. The area that is used for human habitation and the procurement of food and fuel varies based on population, subsistence strategy, mobility, economy, available technology, and the intensity with which the land is used (Kay and Kaplan 2015). Land use in turn has widely varying effects on the landscape with respect to vegetation composition (Höhn and Neumann 2012; Mwampamba and Schwartz 2011; Zeidler, Hanrahan and Scholes 2002); biogeochemical cycling (Kaplan, Krumhardt et al. 2010; Vitousek, Mooney, Lubchenco and Mellilo 1997); erosion (Ciampalini, Billi, Ferrari, Borselli and Follain 2012; De Brue and Verstraeten 2014; Vanwalleghem et al. 2017); fire regimes (Battistel et al. 2017; Pfeiffer, Spesser and Kaplan 2013); and hydrology (Russell, McCoy,Verschuren, Bessems and Huang 2009; Xing et al. 2014).

Deforestation and species extinction are the most commonly cited examples of human influence on the environment in sub-Saharan Africa (e.g. Fairhead and Leach 1995, 1996; Norris et al. 2010), and at least one study has shown that present-day patterns of tree cover are more strongly controlled by human land use than by climate (Aleman, Blarquez and Staver 2016). However, the implications of human land use are not necessarily negative and there are several examples of sustainable agricultural practices or other forms of beneficial land management that might preserve or increase biodiversity (e.g. Backes 2001; Butzer 1996; Denevan 1995; Fairhead and Leach 1996; Heckenberger, Christian Russell, Toney and Schmidt 2007; Niemeijer 1996), or even mitigate climate change (Solomon et al. 2016).

How humans influenced their environment in the past and when that influence began are thus topics of vigorous debate (e.g. Ellis, Maslin, Boivin and Bower 2016; Fischer-Kowalski, Krausmann and Pallua 2014; Foley et al. 2013; Kaplan, Pfeiffer, Kolen and Davis 2016; Lewis and Maslin 2015; Ruddiman 2005; Smith and Zeder 2013; Vanwalleghem et al. 2017). In some parts of the world these effects are easily detected, because of the relatively recent arrival of humans on the landscape (e.g. Douglass and Zinke 2015; McWethy, Whitlock, Wilmshurst, McGlone and $\mathrm{Li}$ 2009), or the unmistakable impact of urbanization and extractive industries (e.g. Kaplan, Krumhardt and Zimmerman 2011; Uglietti, Gabrielli, Cooke, Vallelonga and Thompson 2015). In other areas, the line between natural climate-driven change and human niche construction is harder to define (e.g. Braje and Erlandson 2013; Glikson 2013; Wright 2017). It has even been proposed that the development of pastoral economies in the Sahara may have had consequences for the end of the African Humid Period c. 8000-4500 years ago, either hastening it (Wright 2017) or conversely delaying it (Brierley, Manning and Maslin 2018).

In the majority of sub-Saharan Africa, the most important change in human-environment relations of the precolonial era arose in the context of the 
steady southward and eastward expansion of early Bantu-language speakers, frequently referred to as the Bantu expansion (Bostoen et al. 2013, 2015; de Luna 2017; Grollemund et al. 2015; Rowold, Perez-Benedico, Stojkovic, Garcia-Bertrand and Herrera 2016; Russell, Silva and Steel 2014). This period is characterized by the establishment of a fully developed suite of domesticated crops and iron metallurgy to areas previously occupied by hunter-gatherers and sometimes pastoralists (Marchant et al. 2018). This means that, particularly in southern Africa, there is a clear distinction between the Late Stone Age and the Iron Age that correlates with land-use practices (Huffman and Schoeman 2011; Mitchell 2013a; Pwiti 1996), though the term 'Iron Age' is increasingly falling out of favor (e.g. Maggs 1992). In the northern tropical regions of Africa, the distinction between human and natural influences on the environment is less clear (Casey 2013; Lavachery 1998), and in some cases, highly controversial (see Marchant et al. 2018 for a comprehensive review of this for East Africa).

The vegetation of the Dahomey Gap is a classic example of the debate over human versus natural causes of land-cover change. The present-day potential vegetation of this region is characterized by semi-evergreen forests and savannas, which separate the evergreen broadleaf rainforests of West and Central Africa (White 1983). Palaeoecological reconstructions suggest that this gap between rainforests developed between c. 2550 and 1450 BC (c. 4500 and 3400 BP) (Salzmann and Hoelzmann 2005), and opinions are divided as to whether human land use contributed to the current vegetation composition of the area. Sowunmi (1999) suggested that an increase in pollen from the oil palm (Elaeis guineensis), beginning c. 1550-1050 BC (c. 3500-3000 BP), might have been due to both natural and human influence, and related this to evidence from Kintampo culture archaeological sites in Ghana that suggested the Kintampo may have been actively cultivating the palms. This link between oil palm and human influence has also been made in other areas (see for example Assi-Kaudjhis, Digbehi, Roche and Lezine 2010). Some authors caution, however, that oil palm should not be used as a proxy for human activity, because it is a light-demanding pioneer species that would naturally thrive in a recovering secondary forest; there is therefore a danger of overestimating human influence as compared to natural, climate-driven changes (Maley and Chepstow-Lusty 2001; Salzmann and Hoelzmann 2005).

Thus, while oil-palm pollen is a good indicator of changing land-cover composition, it is not a good indicator of the cause of that change. Recent studies suggest that anthracological analysis would be a less ambiguous recorder of land use and anthropogenic influence in the area (Eichhorn and Neumann 2014; Höhn 2007; Höhn and Neumann 2012, 2016; Hubau et al. 2014; Huysecom, Ozainne, Lespez, Garnier et al. 2015; Morin-Rivat 2017; Morin-Rivat, Biwole et al. 2016; MorinRivat, Fayolle et al. 2014; Vleminckx et al. 2014). While detailed archaeological research has been conducted on the effects of farming and firewood harvesting on specific landscapes (e.g. Höhn 2007; Höhn, Franke and Schmidt 2018; Höhn and Neumann 2012), these studies cover only individual sites or small regions, and provide a very incomplete picture of what might have happened on a larger western African scale. 
The first and second millennia $\mathrm{BC}$ are characterized by major vegetation changes across western Africa: palaeoecological reconstructions suggest that areas that were previously mature forest and swamp forest were replaced by pioneer species, secondary forests, and grassland areas (Lézine and McKey 2013; Maley and Vernet 2013; Ngomanda et al. 2009; Salzmann and Hoelzmann 2005). The timing of this 'forest crisis' correlates with major societal shifts in the archaeological record of the region, and previous studies concluded that a large-scale climatic shift in the late Holocene may have been responsible both for the sociocultural dynamics and for environmental changes over a large area (Breunig 2013; Breunig and Neumann 2002).

The standard interpretation is that a shift towards regionally drier climate after 2000 BC led to forest disturbances and dieback that created openings in the landscape. This forest change in turn facilitated the expansion of farming and the spread of proto-Bantu speaking populations from their homeland in northern Cameroon through Central Africa to the east and south of the continent (Bostoen, Clist et al. 2015; Bostoen, Grollemund and Muluwa 2013; de Luna 2017; Grollemund et al. 2015; Lézine and McKey 2013; Neumann, Boeston et al. 2012a; Ngomanda et al. 2009; Russell, Silva and Steel 2014).

On the other hand, analyses of marine sediments recovered in the Gulf of Guinea led Bayon et al. (2012a) to propose that the Central African forest crisis, and subsequent increase in erosion and chemical weathering, could have been caused by anthropogenic deforestation for agriculture and metallurgy. This theory was opposed by several authors (Lézine et al. 2013; Maley, Giresse, Doumenge and Favier 2012; Neumann, Eggert et al. 2012b; Oslisly, White et al. 2013b). Neumann, Eggert et al. (2012b), for example, pointed out that the terrestrial evidence from archaeological sites required to support this hypothesis was lacking, and that the land use of early farming societies in the rainforest would have been on too small a scale to have caused a major deforestation event. Lézine et al. (2013) suggested that a chronological lag between reconstructed vegetation changes and evidence of human expansion through the northwestern edge of the Central African forests proved that climate change was the primary driver of land cover changes.

Despite this criticism, Bayon et al. (2012b) maintained that even small-scale shifting cultivation could have been sufficient to cause the increased erosion and chemical weathering found in the marine core. Furthermore, palaeoenvironmental and archaeological archives that cover the main forest crisis period are subject to large uncertainties in dating because of a radiocarbon calibration plateau in the mid-late first millennium BC (Hajdas 2008).

Thus, environmental and human change during a critical period in western Africa's history are poorly understood. In order to better understand human-environment interactions in the past, researchers are increasingly turning to interdisciplinary, multi-proxy, and modeling methods (e.g. Boivin et al. 2016; Contreras 2016; Kaplan, Krumhardt et al. 2010; Mayle and Iriarte 2014). Modeling human-environment interactions may allow us to quantify human influences on the physical environment, such as deforestation rate, and at the very least, to rule out certain hypotheses as unrealistic. Providing models with appropriate information on land-use pattern and process is, however, challenging. 
While crop suitability and productivity can be modeled on the basis of environmental variables such as soil type, aspect, latitude, and rainfall, the distribution of people in the landscape is rarely so straightforward. Land use is not only influenced by the physical environment but is also a product of historical, cultural, and societal factors that cannot easily be predicted, and aspects of human culture and agency sometimes defy functionalist theories and ecologically predictive models. For example, the archaeologically documented settlement density of the Tichitt Tradition sites of Mauritania clusters in a pattern opposite to that which would be expected based on water availability, suggesting that some other, cultural, factor may have influenced site locations (MacDonald, Vernet, Martinón-Torres and Fuller 2009).

Fortunately, the archaeological record provides a great deal of valuable information about past human subsistence, and excellent fieldwork has been conducted in western Africa. Unfortunately, the data available for this region are strongly heterogeneous in geographic coverage, thematic and temporal resolution, and general quality. To overcome the limitations of these widely disparate observations and provide a continuous, standardized way of considering land-use change in western Africa, a synthetic approach may be valuable.

Here we present an atlas of subsistence livelihoods in prehistoric West and western Central Africa, based on a broad synthesis of archaeological, archaeobotanical, archaeozoological, historic, linguistic, genetic, and ethnographic data. The atlas uses a classification system we outlined in an earlier paper (Kay and Kaplan 2015), which is revised and simplified here to focus on agricultural livelihoods. The purpose of our maps is to represent in space and time the distribution of various livelihoods and therefore land uses. The maps and their underlying database will have a wide range of uses, including informing quantitative human-environment models, qualitative interpretation of palaeoenvironmental records, and future field data collection efforts.

\section{Study Area}

This study covers West Africa and a portion of northwestern Central Africa (Fig. 1a). The study area is bounded on the north by the central Sahara Desert (c. $20.5^{\circ} \mathrm{N}$ ) and on the west by the Atlantic Ocean (c. $17.5^{\circ} \mathrm{W}$ on the coast of Senegal). The southern boundary is where the Congo River meets the Atlantic on the border between Angola and the Democratic Republic of Congo (DRC) (c. $6^{\circ} \mathrm{S}$ ). The eastern boundary was determined by the largest extent of Lake Mega-Chad, and it runs from eastern Chad, through the Central African Republic, and central Congo Basin (c. $\left.21^{\circ} \mathrm{E}\right)$. This area includes the probable centers of domestication of African rice (Oryza glaberrima), pearl millet (Pennisetum glaucum), cowpea (Vigna unguiculata), and small millets (fonio: Digitaria exilis; black fonio: D. iburua; and Guinea millet: Brachiaria deflexa), as well as the proto-Bantu language homeland in northern Cameroon, from which the Bantu expansion brought agriculture and metallurgy south and east throughout the continent (Bostoen, Clist et al. 2015; Bostoen, Grollemund and Muluwa 2013; de Luna 2017; Grollemund et al. 2015; Rowold, PerezBenedico, Stojkovic, Garcia-Bertrand and Herrera 2016; Russell, Silva and Steel 


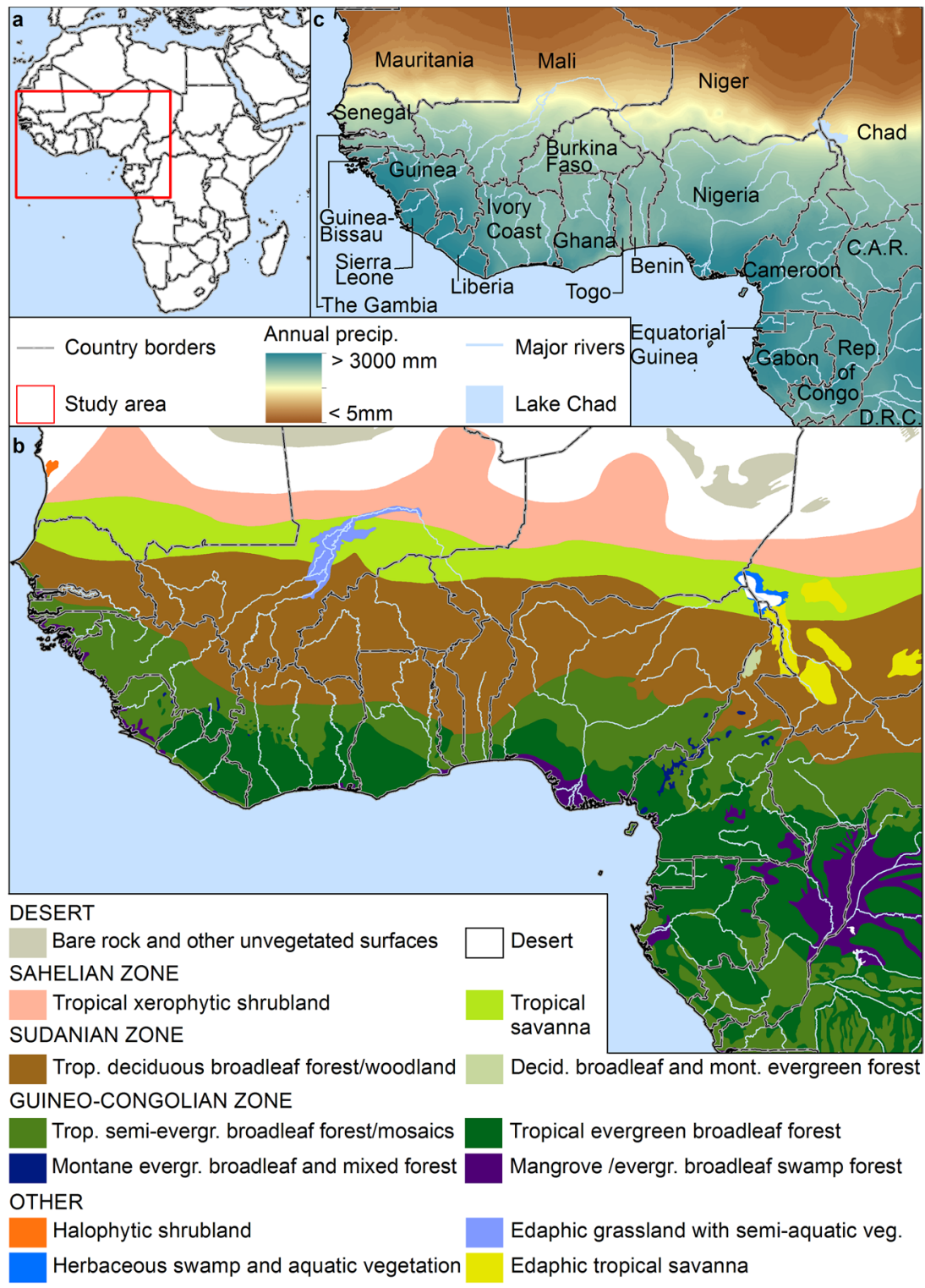

Fig. 1 Maps showing a the location of the study area, $\mathbf{b}$ the potential natural vegetation zones adapted from White (1983), and $\mathbf{c}$ the average annual precipitation gradient from Hijmans et al. (2005)

2014). Understanding these key developments in human history requires an appreciation of the diverse physical environments in which they took place.

Western Africa is notable for its series of latitudinal vegetation bands (Fig. 1b) that correspond to the gradient in mean annual precipitation (Fig. 1c). From north to south, vegetation ranges from the hyper-arid and barren desert landscapes of the 
Sahara, through the seasonally arid shrubland and savanna of the Sahel, into more humid Sudanian savannas and tropical semi-evergreen woodlands, to the tall tropical evergreen forests of the Guineo-Congolian region abutting the Gulf of Guinea. Azonal vegetation assemblages are important in some parts of western Africa, particularly along rivers and lakeshores, in mountains, and on certain types of bedrock and soils. These biogeographic zones form an important basis for human subsistence both in the past and present because they influence the distribution of vegetation and soils, animal habitats, pathogens, and the ease of travel.

South of the Sahara Desert, the band of xerophytic shrubland and savanna known as the Sahel forms a transition zone between the desert and the more mesic Sudanian vegetation further south (White 1983). Both the vegetation and the people of the Sahel are dependent on seasonal rains that come with the African monsoon system, and the region is sensitive to interannual and decadal-scale climate variability that can result in episodes of prolonged drought (Lespez et al. 2011; Maranz 2009). Moving southward, the savannas of the Sahel transition to the Sudanian Zone, a band of humid savannas and drought-deciduous forests and woodlands. In the southern and southeastern part of the study area, Guineo-Congolian vegetation types dominate; these include semi-evergreen broadleaf forests and tall evergreen broadleaf rainforests.

Within this series of vegetation bands are several regions that do not conform to the climatic gradient due to edaphic conditions. The Sahel is traversed by major rivers that originate in the Guinea Highlands in the southwestern part of the study region. Floodplains along the Senegal and Niger Rivers create large areas of mesic vegetation characterized by wetlands and gallery forests that form a stark contrast to the surrounding savannas and semi-deserts. The most important of these regions is the Inland Niger Delta, an extensive floodplain that forms where the Niger and Bani rivers converge in present-day Mali and creates a humid grassland environment interspersed with semi-aquatic vegetation. Owing to its shallow depth and flat topography, the littoral of Lake Chad is characterized by a highly variable zone of herbaceous swamp and aquatic vegetation. South and east of Lake Chad, a large area of seasonally inundated grassland and savanna occurs on cracking clay substrates that were deposited during Lake Chad highstands. Halophytic vegetation is present in parts of coastal Mauritania as well as in small oases across the Sahara. Two types of montane vegetation are present in the highlands of western Africa: montane evergreen broadleaf and mixed forest in Cameroon and Nigeria, as well as small parts of the Guinea highlands, and Mandara Plateau deciduous broadleaf and montane mixed forest in the Mandara Mountains of northern Cameroon and adjacent parts of Nigeria (White 1983). At the Atlantic coast and the outlet of the Niger river, evergreen broadleaf swamp forests and coastal mangroves dominate the landscape.

\section{Materials and Methods}

In this paper, we present the results of an archaeological, archaeobotanical, archaeozoological, linguistic, and ethnohistorical data-synthesis project, where we categorized and mapped the livelihoods of West and western Central Africa from 1800 BC 
to $\mathrm{AD} 1500$, focusing particularly on changing agricultural practices. We chose to begin with $1800 \mathrm{BC}$ in order to capture several important regional developments, although the earliest evidence of domesticated crops in the region precedes this date. Ongoing work continues to push back the dates of the earliest evidence for domesticated crops in West Africa and the process of domestication (Fuller, Denham et al. 2014; Manning, Pelling, Higham, Schwenniger and Fuller 2011). Currently, the earliest evidence for domesticated pearl millet comes from Karkarichinkat Nord (KN05) and likely pre-dates 2400 BC (Manning et al. 2011). This is one of several sites in the lower Tilemsi Valley of Mali that date to between 2800 and 1800 $\mathrm{BC}$ and were intensively occupied by agropastoralists, who also relied heavily on fishing (Finucane, Manning and Touré 2008; Manning et al. 2011). However, these early agricultural communities were few and far between, and it is likely that the low population densities probable in that period would have had minimal impact on their surroundings. This study focuses on the slightly later period, when agricultural practices spread throughout the region, more intensive and specialized methods were developed, populations increased, and additional land uses for metallurgy and commerce were incorporated into local livelihoods. The end date for this study was set at AD 1500, when the introduction of American domesticates through the Columbian exchange began to modify existing indigenous agricultural strategies.

The data for this study were primarily collected from published work. In addition, several of the authors contributed unpublished data or regional interpretations based on their field experience. In order to facilitate the collection and synthesis of large amounts of archaeological data, we constructed a database of archaeological sites, types, coordinates, contexts, radiocarbon or other dates, archaeobotanical and faunal data, and other information pertaining to land use, such as presence/absence of various metallurgical evidence, or soil management techniques. This database is an ongoing project that, at the time of writing, contains records from 1866 archaeological sites, including 3734 radiocarbon or luminescence dates. This database will be made publicly available online on the completion of the project, and a summary table is included as Appendix A (online supplementary material). While primary site data were consulted whenever possible, there are also secondary sources in the database. The use of secondary sources, particularly previous syntheses, greatly facilitated our initial data-gathering efforts, and saved significant time in the collation of thousands of datasets. We have made a good-faith effort to make the database as complete as possible; however, there are likely still sites missing, or analyses to be entered. The database is therefore a work in progress, and will be as long as new research is conducted in the area. Despite this, the current geographic and temporal coverage is sufficient to allow the utilization of this resource. It should be noted that the evidence we are using to inform these maps is very sparsely distributed and is in many areas insufficient to reconstruct diet and land use with any degree of certainty. Many sites in West Africa are not directly radiometrically dated, and there are large areas where no archaeological investigation has been conducted-in many cases, political or geographical access issues have precluded archaeological research. This coverage is even sparser when the sites are limited to those that contain dated botanical or faunal material that can indicate dietary composition (Fig. 2), bearing in mind that faunal and botanical data cannot be directly translated into diet/economic 


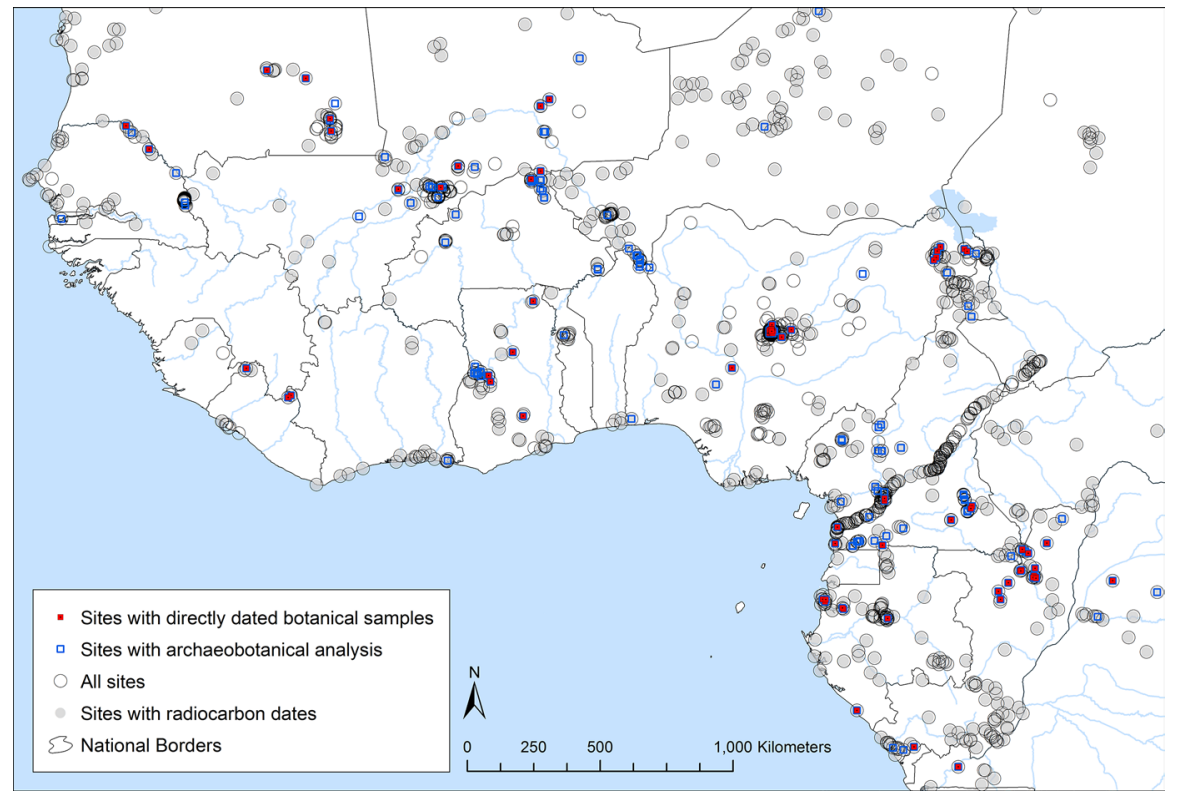

Fig. 2 Distribution of archaeological sites, dates, archaeobotanical analysis, and directly dated botanical samples currently in the database

activities due to taphonomic issues such as types of depositional environments and differential preservation. However, sites without archaeobotanical or zoological sampling, or without radiometric dates, are still useful at a qualitative level for determining degrees of sedentism, distributions of cultural affiliations, and the presence or absence of metallurgy. In areas where data are lacking, we have employed conservative extrapolation based on the authors' expert regional knowledge and current opinions. Because of these challenges, the maps are subjective rather than directly interpolated. Despite these caveats, our maps are a distinct improvement on those produced by scholars from other disciplines-for instance, the KK10 and HYDE maps (Kaplan, Krumhardt et al. 2010).

It is important to note that the initial appearance of small-scale food production in the atlas closely follows that of the first archaeobotanical evidence for pearl millet cultivation. The traditional understanding of the process of plant domestication is that over long periods of time, societies would either manage beneficial taxa in the landscape or practice the husbandry of wild species, gradually selecting for favorable characteristics leading to morphological changes in the plant. In grains like rice and millets, these morphological changes are measurable, because the parts of the plant diagnostic of the domestication process are recoverable in the archaeobotanical record (Fuller, McDonald and Vernet 2007; Fuller, Denham et al. 2014). In vegetatively propagated plants, like yams and bananas, this process is harder to detect due to an almost total lack of preservation of soft tissues in archaeological contexts. While it is possible that there were localized domestication events or the husbandry of wild crops in forest areas prior 
to the arrival of Sahelian cereal crops, there is no archaeobotanical evidence. This could be due to the poor preservation conditions in tropical soils, the perishable nature of forest crops such as yams (Dioscorea cayanensis and D. dumentorum), or a general lack of widespread archaeobotanical sampling. However, we have decided to use archaeobotanical evidence, at least for the first occurrences of farming, and only incorporate other lines of evidence for subsequent developments. Future work may produce earlier evidence for cultivation, but until then we will not extrapolate across vegetation zones. We do, however, make the assumption that once farming has occurred in an area, that knowledge and ability would persist in the population of the region, and unless there is subsequent evidence of absence/abandonment then we assume both a continuation of farming practices in the region and that other locally available crops (e.g. yams) would have been brought under cultivation.

Evidence from individual archaeological sites was assigned to time-windows based on the calibrated date range of the associated context, or bracketing contexts, using the OxCal 4.2 web interface and the IntCal 13 calibration curve with 95\% confidence (Bronk Ramsey 2009; Reimer et al. 2013). For some older radiocarbon dates, with large standard error ranges, some subjective interpretation was required, since the calibrated range included more than one time-window. The map for $600 \mathrm{BC}$ represents a wider window of time than the others, due to the large probability distributions associated with the radiocarbon calibration plateau of the mid 1st millennium BC. This time period is effectively the beginning of the Iron Age in the region, though not for all parts of the region. Time-window intervals for this study were chosen by starting at the radiocarbon plateau map (600 BC) and moving out in 400-year increments until the entire period of interest was covered; the only exception being a single 500-year gap between AD 600 and 1100. It is hoped that in the future a detailed study of the historic records might be able to refine the 900-year range of our last three maps down to a centennial timescale.

The maps were created by manually drawing polygons in ArcGIS, based on the authors' broad understanding of temporal and geographic trends; the polygons were then refined by comparing the boundaries to data available from sites in the database. The size of Lake Chad-and therefore the potential distribution of fishing around it-was roughly mapped according to the water levels published by Maley (2000) and Brunk and Gronenborn (2004), and shapefiles for different time-windows were produced using the ArcGIS spatial analyst contour tool on the Multi-Error-Removed Improved-Terrain DEM (MERIT-DEM) published by Yamazaki et al. (2017). The mapping went through an iterative evaluation process, with the co-authors commenting on several earlier versions prior to publication. The process of spatial generalization is of course very complex, and the atlas therefore represents a hypothesis of the most probable distribution and spread of agricultural land uses in western Africa, given our current knowledge. Thus, it should be edited as new data become available, but also, for large parts of West Africa, verified by future field investigations and detailed archaeobotanical and faunal sampling strategies. 
Table 1 Showing the relationship between the previously defined (Kay and Kaplan 2015) and revised categories

\begin{tabular}{ll}
\hline Kay and Kaplan (2015) & This paper \\
\hline Hunter-gatherers & Hunting and gathering \\
Fisher-gatherers & Fishing \\
Forager-horticulturalists & Small-scale food production \\
Neolithic farmers & Settled farming \\
Early Iron Age farmers & Diversified farming \\
Late Iron Age farmers & Floodplain farming with rice \\
West African floodplain cultivators & Paddy rice farming \\
& Masakwa farming \\
Pastoral-Neolithic & Pastoralism \\
Pastoral Iron Age & \\
No equivalent previously described category & Upland rice farming \\
& Terrace farming \\
& Raised-field farming \\
\hline
\end{tabular}

\section{Results}

The results of this study are both a revision of the livelihood categories previously described by Kay and Kaplan (2015), and an atlas of land-use maps showing the distribution of those categories within the geographic bounds of West and western Central Africa for nine time-windows covering the period 1800 BC-AD 1500.

\section{Revised Categories}

We simplified the nomenclature of the categories as compared to Kay and Kaplan (2015), in order to make them more applicable to other geographic and cultural regions, and to focus more clearly on agricultural production and land use. The revised, new, and consolidated categories, and their relationships to those previously described by Kay and Kaplan (2015) are summarized in Table 1. For expediency, this revision and mapping have been restricted to the smaller case-study area of western and parts of central sub-Saharan Africa, but future work will expand the coverage to include the rest of sub-Saharan Africa. Additionally, the categories defined here also fit into a broader classification of primary land-use type and relative labor input/landscape modification (Fig. 3). The individual categories are described in the following sections.

\section{Hunting and Gathering}

This category covers societies that rely on wild resources for $100 \%$ of their annual diet. These groups might have also traded hunted game or labor hours with nearby 


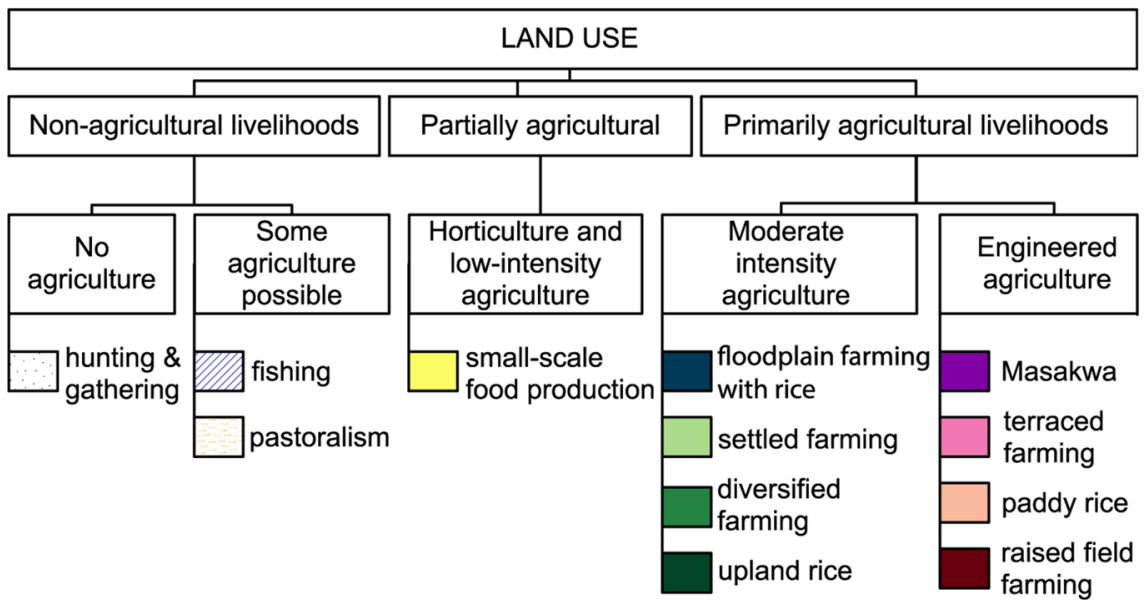

Fig. 3 Flowchart showing the levels of classification: primary livelihood types, relative reliance on agriculture and land-use intensities, and individual categories. Non-agricultural livelihoods are those where the presence of agriculture is not necessary to the overall definition of the category, and are represented on the atlas maps as overlays. Both fishing and pastoralism can incorporate small amounts of agriculture, but only if they overlap with agricultural categories

farmers or pastoralists, as many modern Pygmy groups do (e.g. Binford 2001), and practiced landscape management with fire (to varying degrees), the promotion of beneficial plant species, and the intensive gathering of wild cereals (Archibald, Staver and Levin 2012; Fuller 2007; Huysecom, Rasse et al. 2009). Additionally, during our period of interest, all societies would have utilized pottery; this level of technology has been present in West Africa since at least 9400 BC (Huysecom, Rasse et al. 2009), and was ubiquitous across the continent by the beginning of our study period. The influence of hunter-gatherers on the landscapes they occupied will have fluctuated greatly based on both cultural and environmental variables, so additional research may reveal a need to further sub-divide this category.

Archaeologically, sites were considered to belong to this category if they were microlithic (S. K. McIntosh 2001) and/or had archaeobotanical or faunal assemblages consisting of only wild species. Unfortunately, a large number of sites that fit into this category are either undated, or only relatively dated based on a seriation of the stone tools or pottery from the sites (Davies 1967). The mapped distribution is therefore partially based on genetic studies (Patin et al. 2013; Quintana-Murci et al. 2008), modern Pygmy distributions (Binford 2001), and environmental gradients, while also including any radiometrically-dated archaeological sites that met the criteria. Since this study is primarily focused on mapping agricultural livelihoods, hunter-gatherer sites (those lacking any evidence of domesticates) are not discussed.

\section{Fishing}

Groups specializing in fishing obtain the largest percentage of their diet from aquatic resources, making them primarily a foraging group. However, this category is highly 
diverse and can also incorporate small-scale agriculture and stock-keeping to some degree, as well as either permanent or seasonal sedentism. Specialized fishing sites occurred throughout the entire time period considered. They have been identified in the archaeological record around the margins of major water bodies such as Lake Chad (Holl 2002; Linseele 2007, 2017); the Niger River Bend (Cook 2000; MacLean and Insoll 1999); the Inland Niger Delta (Jousse, Obermaier, Raimbault and Peters 2008; Jousse, Person et al. 2009); and the coastal margins of West Africa (Linares de Sapir 1971; Polet 1995); however, fishing activities could have taken place opportunistically on all manner of water bodies (Mitchell 2013b). Seasonally inundated areas have especially been linked to important subsistence fishing activities, because fish spawning in floodplains are easy prey and provide opportunities for communal harvesting (Linseele 2017). Ethnohistoric and archaeological examples of fishing societies show that they often trade with nearby groups for other types of food or materials (Gronenborn 1998; Linseele 2007, 2017; Macdonald and Van Neer 1994; Mitchell 2013b).

The distribution of fishing on the maps changes slightly between time-windows, based roughly on climatically driven hydrology; this does not mean that the distribution of fishing societies did not change for other reasons as well. The current maps show only a coastal buffer, major inland water bodies (e.g. the Niger River bend and the margins of Lake Chad), palaeo-lakes near archaeological sites containing fish-bones, and modern vegetation zones that are seasonally inundated. Inland-lake, flood-plain, and riverine fishing could be better estimated in future modeling by simulating the availability of surface waters dynamically as a function of climate, slope, and soil permeability. While the presence or absence of this livelihood strategy was partially dependent on hydrological variability, our understanding of other variables is sometimes clouded by taphonomic processes that can destroy fragile fish bones, or limited faunal sampling on archaeological sites (Linseele 2017).

\section{Pastoralism}

For the purposes of this primarily agricultural study, the pastoralism category represents societies that relied predominantly on domestic animal production for subsistence or livelihood. This may include strategies that were mainly based on cattle (Bos spp.), caprines (Ovis aries and Capra hircus), or camels (Camelus dromedarius), and were limited by water and fodder availability. These systems would also have varying degrees of mobility, and be supplemented by gathered wild resources, hunting, and a small contribution from domesticated crops when climatic conditions allowed. Trade and exchange with neighboring farmers would have provided additional food resources.

This category is a broad generalization of a diverse collection of animal production systems. Ongoing work (Phelps and Kaplan 2017) will further sub-divide and categorize these systems for modeling purposes. The currently mapped distribution of pastoralism considers only the presence of animal-based pastoral production systems; areas of overlap with farming categories denote either pastoral groups who also incorporate an agricultural component or a mosaic of strategies in the landscape. 


\section{Small-Scale Food Production}

This category is a combination of two categories defined by Kay and Kaplan (2015): forager-horticulturalists and Neolithic farmers. It has been renamed to better encompass the varying crop sets of different climatic regions, while still maintaining the relative dietary proportions. This group is still primarily reliant on foraged wild resources, but supplements that diet with either small-scale cultivation of domesticates or husbandry of wild species (Smith 2001), as well as stock-keeping. In many cases, sites were assigned to this category when domesticates were present but not common, and either no information was available about the settlement type, or the settlement was ephemeral. For example, the Final Stone Age of the Tin-Akof area in northern Burkina Faso, where the cultivation of domesticated pearl millet was integrated into a mobile hunting-gathering-fishing system, falls into this category (Höhn and Neumann 2012).

\section{Settled Farming}

This category relied primarily on a limited set of regionally available domesticated crops-in West Africa this meant pearl millet ( $P$. glaucum) and sometimes cowpea ( $V$. unguiculata); domestic animals would have been kept, the diet supplemented with foraged wild resources, and the husbandry of regionally available wild species practiced. Little to no information is available on soil-management techniques, so none are assumed, though ethnographic evidence suggests that pearl millet and cowpeas would have been intercropped, and some degree of shifting cultivation may have been utilized. Sites were assigned to this category based on a dominance of domesticated grains in the archaeobotanical assemblage, and/or archaeological remains indicative of a sedentary lifestyle. For example, while the majority of Kintampo sites fall into the 'small-scale food production' category, the site of Birimi showed evidence of a more settled village lifestyle reliant on domesticated pearl millet.

\section{Diversified Farming}

This category represents the diversification both of the farming package and of the land-management strategy. In the savanna areas of West Africa this includes the addition of either sorghum (Sorghum bicolor), the small millets (i.e. fonios), or both to the existing farming system, and elsewhere the addition of other crops (e.g. bananas) whenever they became available in the region. It also implies more complex field-management techniques, such as regular fallow systems (Höhn and Neumann 2012), infield/outfield systems (Widgren 2010), or the creation of 'dark earths' (Fairhead and Leach 2009; Fairhead, Leach and Kojo 2012). These groups would also keep domestic stock and supplement their diet with foraged wild resources. The incorporation of locally available beneficial tree species into agricultural systems was also practiced; this type of park savanna agroforestry is still typical of SudanoSahelian agriculture today (Höhn and Neumann 2012). 
Specific areas and ages of fertility-management techniques are not widely studied in Africa, but this category assumes some amount of soil management. An ethnopedology study conducted in the firgi plains area of the Nigerian Lake Chad Basin found that the different land management techniques of two present-day cultural groups were visible in the micromorphology of the soils (Adderley et al. 2004). Of particular relevance to our work is the village of Tiwa, where the modern Kanuri people manage the fertility of their cultivated soils by fertilizing with manure from their domestic animals, ash and charcoal from cooking, and other 'domestic debris'. The earliest evidence of this system was identified in a soil profile and dated to $\mathrm{c}$. AD 750 (SUTL-1411, 1167 \pm 110 BP) with Optically Stimulated Luminescence (OSL) (Adderley et al. 2004). The soil micromorphology from that depth to the surface was consistent, indicating a long-standing cultural soil modification. The creation of African dark earths has also been documented in traditional farming systems in Liberia and Ghana (Solomon et al. 2016). In the future, should more soil management studies be conducted, this category may be further sub-divided to account for the varying long-term effects of different strategies.

\section{Terrace Farming}

The term terrace is used generally here and includes sediment traps, and terraces built for a variety of purposes, such as soil retention, water retention, and soil creation or improvement (Ferro-Vázquez et al. 2017). The construction and maintenance of agricultural terraces requires substantial labor and time input from the community, and has a significant effect on local landscape processes (Ciampalini et al. 2012; Tarolli, Preti and Romani 2014).

The construction of terraced field systems occurs in several locations in Africa (Grove and Sutton 1989; Lang and Stump 2017; Stump 2010; Widgren 2000, 2010), but within our area and period of interest (western Africa up to AD 1500) this system appears to be limited to the Mandara Mountains of northern Cameroon. Other terraced regions of western Africa, such as the Kofyar in Nigeria (Netting 1993), were likely terraced some time after our study period, and several of these are documented by AD 1800 (Widgren 2018). There has not been any archaeobotanical sampling of these sites, but linguistic and archaeological analysis indicates that the development of terraces was an intensification of a pre-existing food-production system (MacEachern 2012a) through investment in landesque capital (Widgren 2007). Therefore, users of this system would have had access to the same set of domesticated crops as the surrounding diversified farming areas. This system also included stock keeping and would have supported a higher population in a smaller area. While they would still have supplemented the diet with wild resources, the contribution would have been greatly reduced.

\section{Floodplain Farming with Rice}

This category refers collectively to the deep-water (floating rice) (Carney 2001; Catling 1992), riz des mares (pond rice) (Gallais 1967), and décrue (flood recession) (Harlan and Pasquereau 1969) farming types of West Africa. As such it is a catch-all 
for the rich mosaic of different crops and inter-related land uses found along the rivers of the Sahelian and Sudanian portions of our study area, but particularly along the Niger River and its inland delta. The types of farming subsumed in this category specialized in growing African rice (Oryza glaberrima) in either seasonally or permanently inundated areas, while other crops such as millets or sorghum would have been sown as the floods receded, or grown on sandy levees (S. K. McIntosh 1999). In addition to rice and other crops, domestic stock would have been raised on nonflooded land (either naturally or in constructed levees) (S. K. McIntosh 1999), or brought in to graze as waters receded. These diets would also have been supplemented with wild resources. These types of farming dominated large stretches of the Niger River and its tributaries, and were also present on the rivers of coastal West Africa, though archaeobotanical data are lacking in many upstream areas.

The distribution of deep-water rice (common in the Inner Niger Delta) and décrue millets or sorghum would have varied annually and inter-annually with changes in regional climate and monsoon strength (Armitage, Bristow and Drake 2015; Maley and Vernet 2015), because these would have affected not only water levels but also the physical geography of the land forms on the floodplain, particularly in the Inland Niger Delta (Jacobberger 1987; R. J. McIntosh 1983). Due to this variability and a lack of detailed spatio-temporal data to distinguish individual cultivation strategies through time and space, we have mapped these together. These practices could be further disambiguated and mapped through additional work, particularly archaeobotanical and palaeoenvironmental work, and even ecological niche modeling that incorporates paleoclimate reconstructions. Their patchy distribution throughout a relatively small (on the scale of western Africa) area made the distinction unnecessary for our purposes, but if smaller, regional scale studies are attempted in the future, this category should be sub-divided. Determining the boundaries of deepwater rice farming, for example, will be important for future modeling studies, due to its relevance to methane production, as well as the importance of both rice and the Niger River floodplain in the development of West African societies. Further west, the distinction between floodplain farming and paddy rice farming along the rivers of coastal West Africa is also challenging and will require further work to fully differentiate (see Bezançon 1995 for descriptions of the many rice cultivation types in West Africa and elsewhere).

\section{Paddy Rice Farming}

This system involved the construction of dikes and embankments to trap rain or flood water and irrigate rice paddies for inundated farming. In West Africa, this system was concentrated along the coast where mangrove habitats were converted to rice fields, a process involving several years of construction and desalination before a rice crop could be planted. Coastal paddies which had become too saline were partially abandoned and the accumulated salt deposits were harvested and traded. While African rice was the primary crop, other regionally available crops were also grown in rain-fed fields (e.g. yams and millets) and domestic stock animals were kept where possible. The exploitation of both rain-fed and irrigated crops allowed 
for multiple harvests per year, and a surplus which could be traded (Carney 2001; Catling 1992).

\section{Masakwa Farming}

In this system, naturally occurring floodwaters are trapped in constructed fields so that a second crop can be grown in the dry season. This technique, used to grow a dry-season crop of sorghum, is historically common in the firgi clay plains of the Lake Chad Basin; however, there is little evidence for the antiquity of the practice. While domesticated sorghum was likely introduced to the Lake Chad Basin by the third to fifth centuries AD (Magnavita 2002), the first evidence of the Masakwa farming system comes from a historical source in the 1570s (Gronenborn 2001). For the purposes of this project, Masakwa farming has been included in the AD 1500 time-window based on the assumption that it was an established system in the late 1500 s and therefore already present by the turn of that century.

\section{Upland Rice Farming}

Upland rice farming involved the cultivation of African rice in rain-fed fields on well-drained soils (Johnny, Karimu and Richards 1981). Often, the rice crop would be complemented by other grain crops, as well as a 'kitchen garden'. Groups who specialized in upland rice farming would also keep domestic stock where available, and supplement their diet with wild resources. These systems are ethnographically associated with swidden or shifting cultivation systems, with a fallow period determined by the local soil and vegetation characteristics, as well as population density and available labor. The development and practice of this system was centered in the Mande heartland of the Guinea highlands, and often involved a combination of cultivation strategies, timed to take advantage of the landscape gradient, maturation times, and the seasonal rains. This system was historically documented in Sierra Leone and Liberia as early as 1640, when European travelers began to describe the larger agricultural systems of the area, rather than just the coastal components, but linguistic evidence indicates a much earlier origin (Carney 2001; Fields-Black 2008a).

\section{Raised-Field Farming}

This type of farming has only recently been documented in Central Africa and has not yet been fully studied; however, preliminary research indicates that these fields are present in several areas of coastal Gabon and the western Congo Basin (Richard Oslisly pers. comm. 2017). In other parts of the world this type of farming has been more thoroughly documented, for example, in the Bolivian Amazon (Whitney et al. 2014). Generally, farming on raised fields involves building up soil to create raised platforms in areas that would otherwise be inundated. The construction of these raised fields allows farmers to improve the drainage of seasonally-inundated 

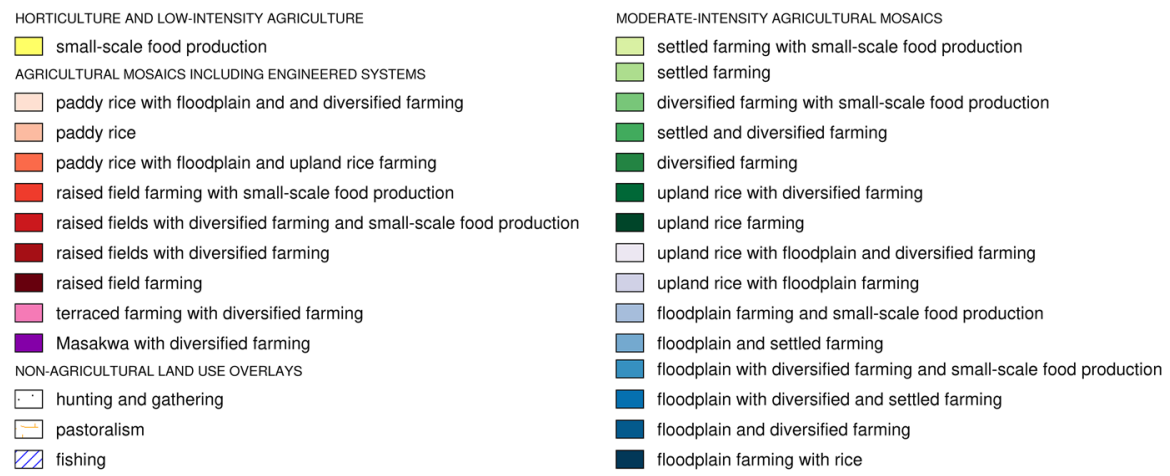

Fig. 4 Master color scheme of all the land-use category mosaics and non-agricultural overlays

lowland soils, which may have both increased productivity and mitigated flood risk (Lombardo, Canal-Beeby, Fehr and Veit 2011).

\section{Land-Use Maps}

In the following section, each map is briefly described in chronological order. Due to the nature and distribution of the information used to create these maps, it is often prudent to show areas of overlap. In some cases, there are clearly two or three distinct groups with different livelihoods; in other areas the distinctions are less clear. For example, in the Dhar Tichitt region, it is unclear whether there is a single group of agro-pastoralists, or separate groups of pastoralists and farmers. Either way, the categories overlap on our maps. Similarly, many sites categorized as hunting and gathering camps might have been created by farming people on a hunting foray, and pastoralists have been known to graze their herds on fallow farmlands. In order to better represent this complex mixture of land uses, many areas are depicted on the maps as a single color representing a mosaic of two or more categories (Fig. 4). The map descriptions focus on the significant changes between time-windows, and are explained geographically using select examples and evidence from individual archaeological sites, regional studies, and historic descriptions (see Fig. 5 for locations mentioned in text).

\section{$1800 \mathrm{BC}$}

By 1800 BC (Fig. 6), several sites in the lower Tilemsi Valley of Mali (e.g. Karkarichinkat Nord), which date to between 2800 and 1800 BC, were intensively occupied by settled farmers and agropastoralists who also relied heavily on fishing (Finucane, Manning and Touré 2008; Manning et al. 2011). Outside of the Tilemsi Valley, the small-scale cultivation of domesticated pearl millet is documented at several sites in the West African Sahel, as well as at several sites in what is now Ghana (D'Andrea and Casey 2002). The large gap between the two areas of small-scale 


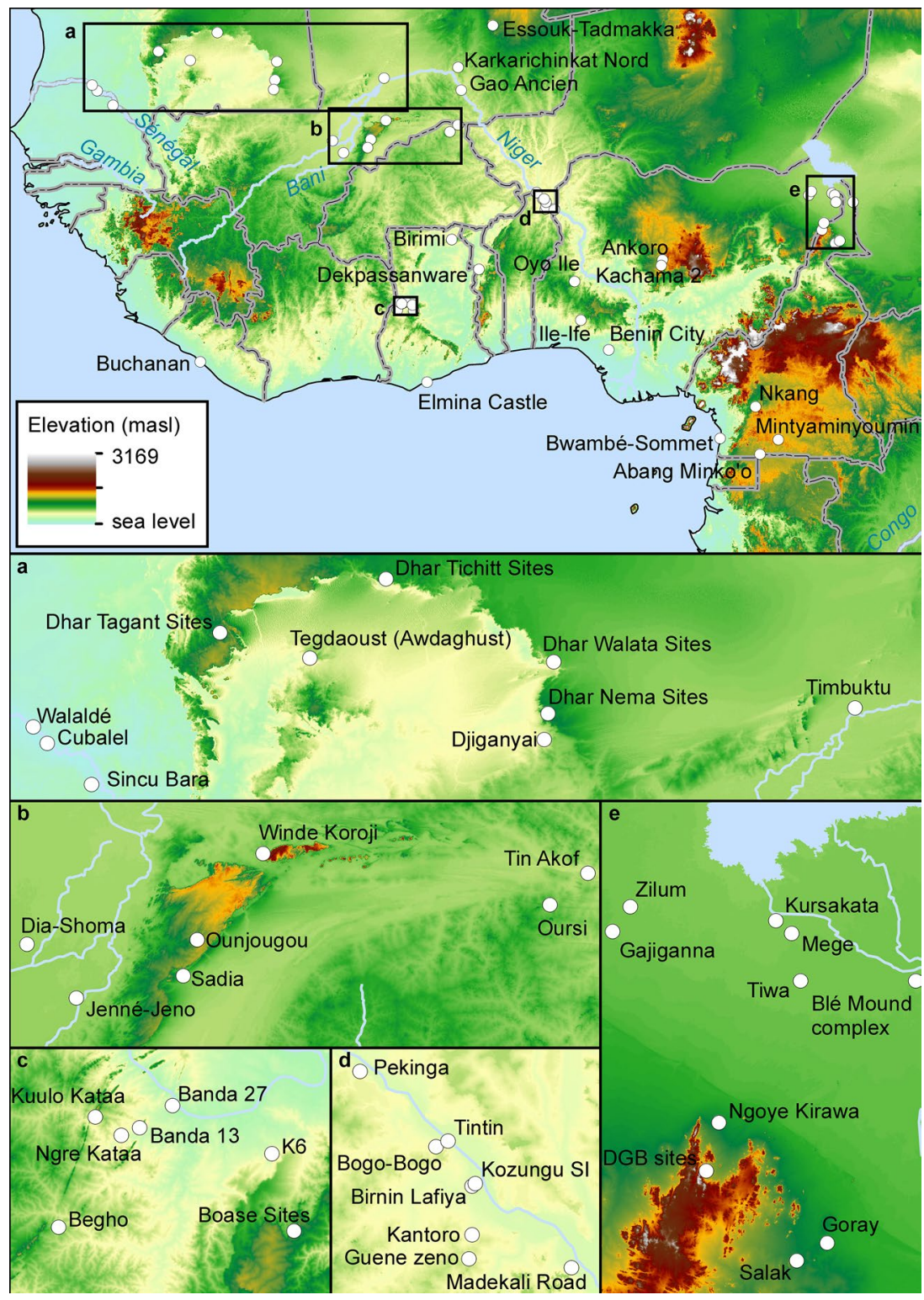

Fig. 5 Topographic map of project area, showing locations and rivers mentioned in text. Site clusters shown in detail include, from west to east: a the Senegal River Valley, the Hodh basin region with the surrounding cliffs (dhars), and the southern Azawad basin near the Niger River; $\mathbf{b}$ the Mema region, the Inland Niger Delta, the Bandiagara plateau and escarpment, the Seno plain, and the southern Gourma region; $\mathbf{c}$ the Banda region of the Black Volta River Basin; $\mathbf{d}$ the portion of the Niger River Valley on the border of Benin and Niger; and e the southern Lake Chad Basin including the Bama Deltaic complex and firgi areas, extending south to include the Mandara Mountains 


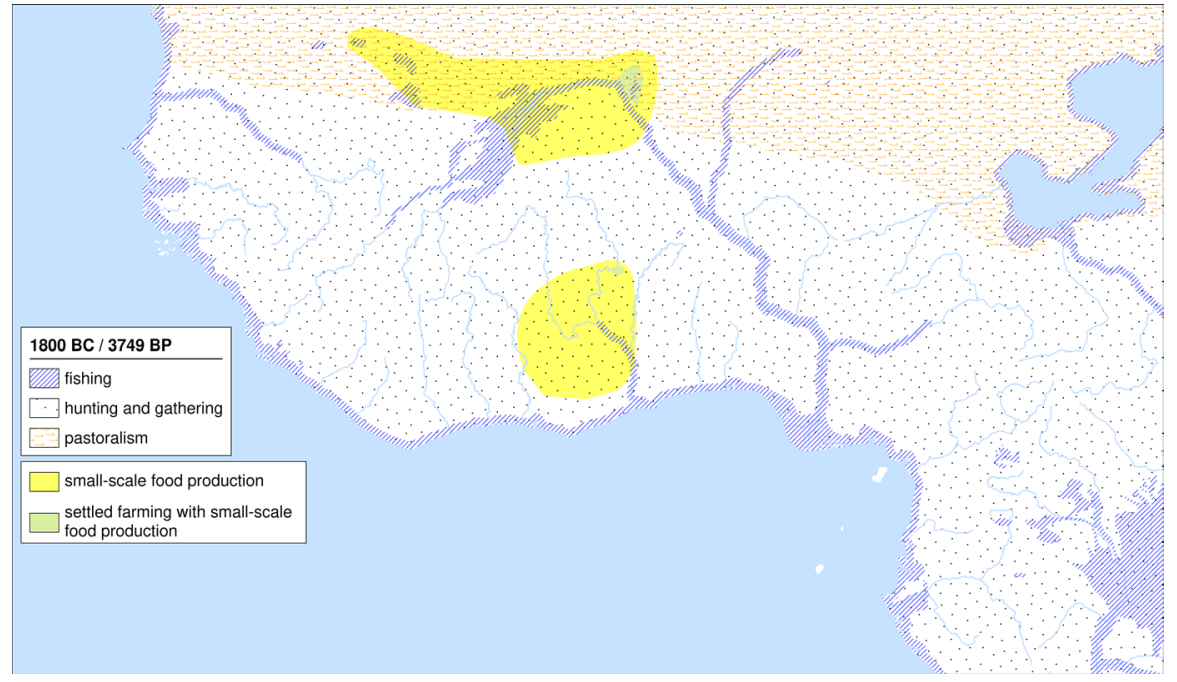

Fig. 6 Map of livelihood distributions in 1800 BC

food production on the map for this time-window is due to an absence of archaeobotanical evidence for domesticates in most of Burkina Faso at that time. However, studies have shown that there was contact between these regions (Ozainne, Lespez, Garnier et al. 2014) and that pearl millet was domesticated in the Sahel zone (Manning and Fuller 2014); further work may therefore provide the archaeobotanical evidence to connect these two areas on the map. The southern boundary of the Sahelian polygon was determined by evidence from the sites of Tin Akof and Oursi in Burkina Faso, and Ounjougou in Mali, where domesticated pearl millet grains were found in contexts dated to approximately this period, but permanent settlements were not (Höhn and Neumann 2012; Manning 2010; Ozainne, Lespez, Le Drezen et al. 2009).

The people of the Tichitt tradition of southern Mauritania have been described as Neolithic agropastoralists (Holl 2009a), though it has not always been agreed whether or not the society was divided between pastoral and agricultural subgroups (MacDonald 2014; Munson 1980). During the Early Tichitt (MacDonald 2013; MacDonald, Vernet, Martinón-Torres and Fuller 2009) or Early Settlement Sequence (Holl 2009a), the archaeological record of the Dhar Tichitt-Walata region indicates the use of morphologically domesticated pearl millet, livestock husbandry, fishing, and high seasonal mobility (Holl 2009a; MacDonald 2013).

The Kintampo Complex of the West African forest-savanna transition has a well-documented artifact assemblage (Davies 1967) and geographic extent (Logan and D'Andrea 2012), and a well-established date range (c. 2100-1400 BC) (Watson 2010). Kintampo sites are associated with the earliest use of domesticates in the region (pearl millet, cowpea, caprines, and cattle: D'Andrea, Logan and Watson 2006; Watson 2010) but also a heavy reliance on non-domesticated products of the forest, particularly oil palm (D’Andrea, Logan and Watson 2006; Logan and 
D'Andrea 2012). The Kintampo are generally considered to have been small-scale food producers, but the expression of that food-production in the archaeobotanical record follows a gradient consistent with the savanna-to-forest ecotone occupied by the Kintampo. Pearl millet is more abundant at Kintampo sites in the Sudanian zone of northern Ghana, but is found as far south as the Boase rock-shelter sites in central Ghana; forest products like oil palm dominate the more southern assemblages in the Guineo-Congolian zone. The site of Birimi in the far north of modern Ghana has the most pearl millet, with 1666 grains identified as either $P$. glaucum or cf. $P$. glaucum, as well as an extensive area of burnt daub architectural remains (D'Andrea and Casey 2002). The area around the village of Birimi has been classified as settled farming, to reflect this increased sedentism and reliance on domesticated grains.

Beginning at approximately $1800 \mathrm{BC}$, the Bama Deltaic Complex of the southern Lake Chad Basin was first occupied by a mobile pastoral group known as the Gajiganna culture (Breunig 2013; Linseele 2017). During the earliest period of the Gajiganna culture (Phase I: c. 1800-1500 BC), there is no evidence for the use of domesticated plants (Klee, Zach and Stika 2004; Ozainne, Lespez, Garnier et al. 2014).

\section{$1400 \mathrm{BC}$}

Major changes following the $1800 \mathrm{BC}$ time-window include the expansion of settled farming systems to the Bandiagara Plateau, and the Dhars of southern Mauritania, but the abandonment of the settled farming sites in the lower Tilemsi Valley. There was also an expansion of small-scale food production across the Sahelian savanna belt and south into the Sudanian savanna zone.

By 1400 BC (Fig. 7), domesticated pearl millet was being used at Djiganyai in the Dhar Néma (Fuller, McDonald and Vernet 2007; MacDonald 2011; MacDonald, Vernet, Martinón-Torres and Fuller 2009) and was found in a potsherd from

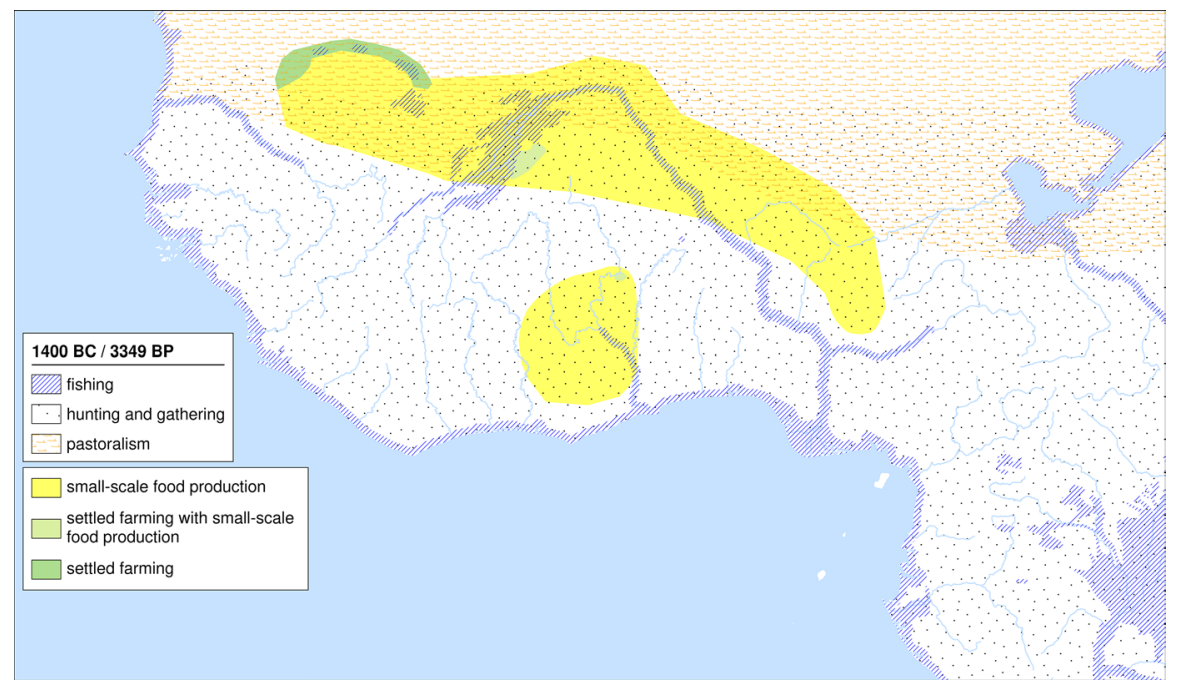

Fig. 7 Map of livelihood distributions in 1400 BC 
phase IIa (c. 1500-1200 BC) at the pastoral site of Gajiganna (Klee, Zach and Stika 2004). The populations of the Dhars Tichitt, Walata, and Tagant all expanded during the Classic Tichitt period (c. 1600-1000 BC), and a hierarchical settlement pattern developed. These stone-walled settlements ranged in size from 2 to 80 ha, and included dwellings, grain storage facilities, tumuli, and large walled areas likely used for agriculture — either for gardens or livestock (MacDonald 2013). This period also saw the beginning of farming villages interspersed with cultivation camps in the Yamé Valley of Mali. The evidence from Ounjougou indicates that not only were the inhabitants farming (and likely stock keeping), but they were also managing the landscape with seasonal burning (Ozainne, Lespez, Le Drezen et al. 2009).

In central Nigeria, the Early Nok (c. 1500-900 BC) had introduced the practice of farming domesticated pearl millet, likely as a result of migration (Franke 2016). Directly dated Pennisetum grains from the sites of Ankoro and Kachama 2 confirmed the antiquity of this practice (Franke 2016). Ongoing work in the region will continue to cement our understanding of the Early Nok period (Alexa Höhn pers. comm. 2017).

\section{$1000 \mathrm{BC}$}

Major changes following the $1400 \mathrm{BC}$ time-window include the expansion of settled farming systems into Dhar Nema, the Méma region, and the Seno plain. Small-scale food production also expanded in the Sahelian savanna zone, reaching as far east as the southern Lake Chad Basin; however, the majority of small-scale food production sites in Ghana had been abandoned by this time.

By 1000 BC (Fig. 8), Tichitt peoples had begun to make use of the Méma region, initially for the seasonal grazing of their livestock but eventually on a more

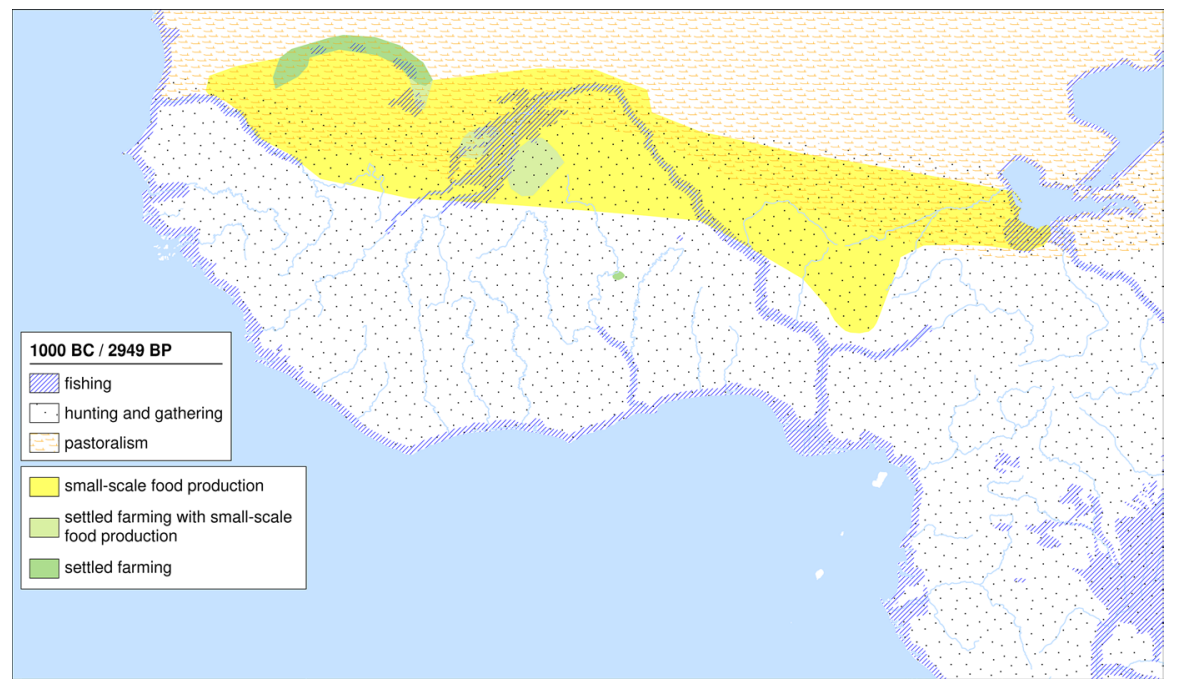

Fig. 8 Map of livelihood distributions in 1000 BC 
permanent basis (MacDonald 2011). This time-window also marks the turning point of the Classic to Late Tichitt transition, when the settlements began to decline in the Dhars Tichitt-Walata (MacDonald 2013). Also by this time, most Kintampo sites had been abandoned; however, there is some evidence for the continued occupation of Birimi (Casey et al. 1997).

In other areas, agriculture was expanding. In the Lake Chad Basin, the mostly pastoral site of Gajiganna had grown more sedentary and the cultivation of domesticated pearl millet had increased by this time (Klee, Zach and Stika 2004). Nearby, in the firgi clay plains, the site of Kursakata had been settled by this time and domesticated pearl millet is found in the earliest layers (Klee and Zach 1999). At the Winde Koroji site complex, the evidence for this period includes a mix of wild and domesticated flora and fauna, and the seasonality is uncertain (MacDonald 1996). We have therefore used this site as a boundary marker for the settled farming polygon in the Bandiagara area for this time. Ongoing work on the samples from Winde Koroji will allow a more detailed understanding of the land-use systems throughout the occupation history of the site (MacDonald, Champion and Manning 2017).

\section{$600 \mathrm{BC}$}

Many important changes to settlement patterns and agricultural regimes occurred across West Africa at this time, and as previously discussed, this time-window has the highest level of uncertainty about dating - events dating to $600 \mathrm{BC}$ might just as easily have occurred closer to $400 \mathrm{BC}$-so this map (Fig. 9) represents the period of the radiocarbon plateau between approximately 800/750 and 400 BC (Oslisly, Bentaleb et al. 2013a; Steier and Rom 2000). Major changes following the 1000 $\mathrm{BC}$ time-window include the expansion of the mapped extent of small-scale food

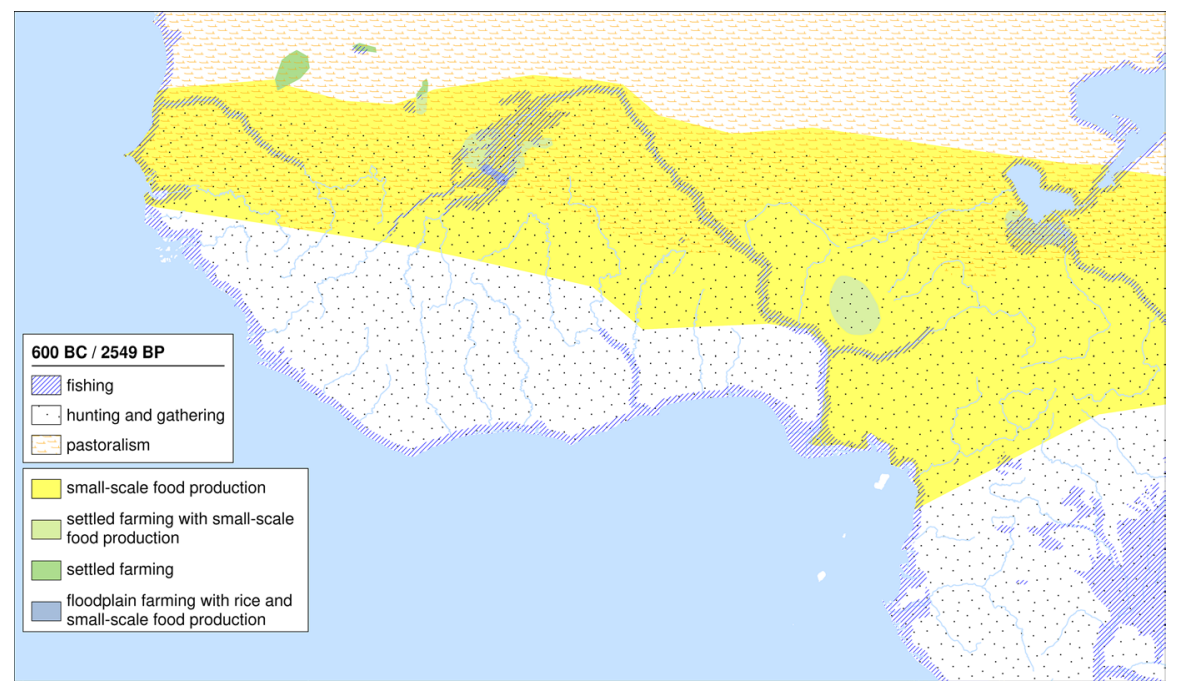

Fig. 9 Map of livelihood distributions in $600 \mathrm{BC}$ 
production west to the coast, east to the edge of the study area, and as far south as the Central African forests and coastal Cameroon. This time-window represents the first southward expansion of agriculture to the forests of Central Africa (such as at Bwambé-Sommet: Eggert et al. 2006; Kahlheber, Bostoen and Neumann 2009a), while at the same time it was retreating from the Hodh Basin of southern Mauritania. Settled farming systems both expanded and fragmented during this period, with new areas of settled farming appearing in the hilly foreland of the Jos Plateau of central Nigeria, and the southern Lake Chad Basin of Nigeria and Cameroon. The settled farming sites on the Bandiagara Plateau were abandoned near the end of this period, but the lower-lying areas to the north and west remained occupied. In southern Mauritania, the Late Tichitt phase marked major changes in settlement distribution, including the abandonment of sites in the Hodh Basin, and the nucleation and fortification of settlements in the Dhars (MacDonald 2011, 2013). Finally, this is the first map showing an area of floodplain farming with rice, in the Inland Niger Delta. The earliest archaeobotanical evidence of domesticated African rice comes from Horizon I at Dia Shoma (c. 800-300 BC), in the Inland Niger Delta (Bedaux et al. 2001; Murray 2007). It is important to note that these rice grains represent a fully domesticated phenotype, but that the evidence for the (earlier) domestication process has yet to be found. Genetic studies suggest domestication may have occurred east of the Guinea highlands and therefore around the borders of western Mali, Southeast Senegal and Sierra Leone (Meyer et al. 2016); it is plausible that rice spread down into the Niger River from its western and southern tributaries. Linguistic evidence also supports this theory and suggests a possible domestication date c. 1500 BC (Carney 2001). Further work in that region may necessitate a revision of several of the rice-farming category sequences on our maps.

There was a decline in settlement on the Bandiagara Plateau around Ounjougou at this time, with some evidence of continued occupation of the Yamé Valley (Ozainne 2006; Ozainne, Lespez, Le Drezen et al. 2009), as well as the arrival of the Zampia tradition in the Gourma (MacDonald 1996). The site of Walalde, in the middle Senegal River Valley, was first occupied during this period (Déme and McIntosh 2006; Murray and Déme 2014). The inhabitants of Walaldé kept domestic cattle and caprines; fished and hunted; cultivated domesticated pearl millet; and collected wild seeds and fruit. Both iron and stone tools were used from the earliest occupation, and at a later point there was iron smelting on site. Interestingly, a thorough archaeobotanical sampling strategy recovered no rice grains, indicating that floodplain farming with rice had not yet reached this part of the Senegal River.

On the Jos Plateau of Nigeria, the Nok culture had begun to rely more heavily on domesticated pearl millet, with other domesticates also present in lower percentages (Kahlheber, Höhn and Rapp 2009b). This is also the period when the Nok began to smelt iron (Holl 2009b; Junius 2016), which likely had implications for the composition of woody vegetation in the landscape (Höhn and Kahlheber 2011).

In the Lake Chad Basin at this time there was a trend toward more nucleated and defensible settlements. At Zilum, a Gajiganna Phase III site in the northern Bama Deltaic Complex, a $1 \mathrm{~km}$ long wall and ditch system surrounded the town, and even its smaller satellite settlements were surrounded by ditches. This settlement pattern change also corresponds with an increase in the finds of domesticated pearl millet 
and cowpea, a shift in the relative percentages of different species in the faunal assemblage, and an increase in specialized craft production (Linseele and Van Neer 2018; Magnavita, Breunig, Ameje, and Posselt 2006). However, the change in the faunal assemblage may not indicate a decrease in the importance of livestock, but rather a change in both the depositional patterns at the site and the environmental composition of the surrounding landscape (Linseele and Van Neer 2018). An increased reliance on agriculture is seen in Mege at this period, where the earliest known evidence for okra (Abelmoschus cf. esculentus) has been found (Bigga and Kahlheber 2011). In contrast, there was a settlement hiatus at Kursakata at this time (Klee, Zach and Neumann 2000).

The first occupation of Dekpassanware, in central Togo, during this period represents the earliest evidence of post-Kintampo agriculture in the area (de Barros 2003, 2006), thus the re-extension of the small-scale cultivation polygon to that area. This time-window also provides the first irrefutable evidence of the expansion of pearl millet cultivation to the coastal portion of the Central African forests. At the site of Bwambé-Sommet, in coastal southern Cameroon, a charred domesticated pearl millet grain from an archaeological context was directly dated to this period (Erl-9176, $2326 \pm 86$ ) (Eggert et al. 2006; Kahlheber, Bostoen and Neumann 2009a). We have tentatively included the site of Nkang in this polygon, due to the finds of domestic caprine remains in a securely-dated context, and the possibility of banana phytolith evidence, though the dating and prevalence of this is debated (Lejju, Robertshaw and Taylor 2006; Mbida, Van Neer, Doutrelpont and Vrydaghs 2000; Neumann and Hildebrand 2009).

\section{$200 B C$}

Following the $600 \mathrm{BC}$ time-window, small-scale food production continued to expand to the south, while contracting from parts of the north. The expansion of these systems to coastal areas is only limited by areas of natural mangrove forest where labor-intensive techniques are required to make the soil cultivable. This time period also saw the final abandonment of settled farming sites in the central dhars of Mauritania (Dhar Tichitt and Dhar Walata), small-scale food-production sites in a large swath south of the Niger River bend, and the expansion of floodplain farming with rice throughout the Inland Niger Delta. This may have been due to a period of aridity that made access to a reliable floodplain desirable (Garnier et al. 2015; Lespez et al. 2011).

By 200 BC (Fig. 10), pearl-millet farming in the Central African forests had expanded to several more sites in southern Cameroon, including Abang Minko'o and Mintyaminyoumin - even as far as Boso-Njafo in the Inner Congo Basin, which is beyond our study area (Eggert et al. 2006; Kahlheber, Eggert, Seidensticker and Wotzka 2014; Neumann, Boeston et al. 2012a). Several studies have documented an increase in population in tropical Africa at this time (Garcin, Deschamps et al. 2018a; Morin-Rivat, Biwole et al. 2016; Morin-Rivat, Fayolle et al. 2014; Wotzka 2006). Also by this time, proto-Bantu language speaking farmers had expanded out of West Africa, bringing both their language and crop set towards the east and south 


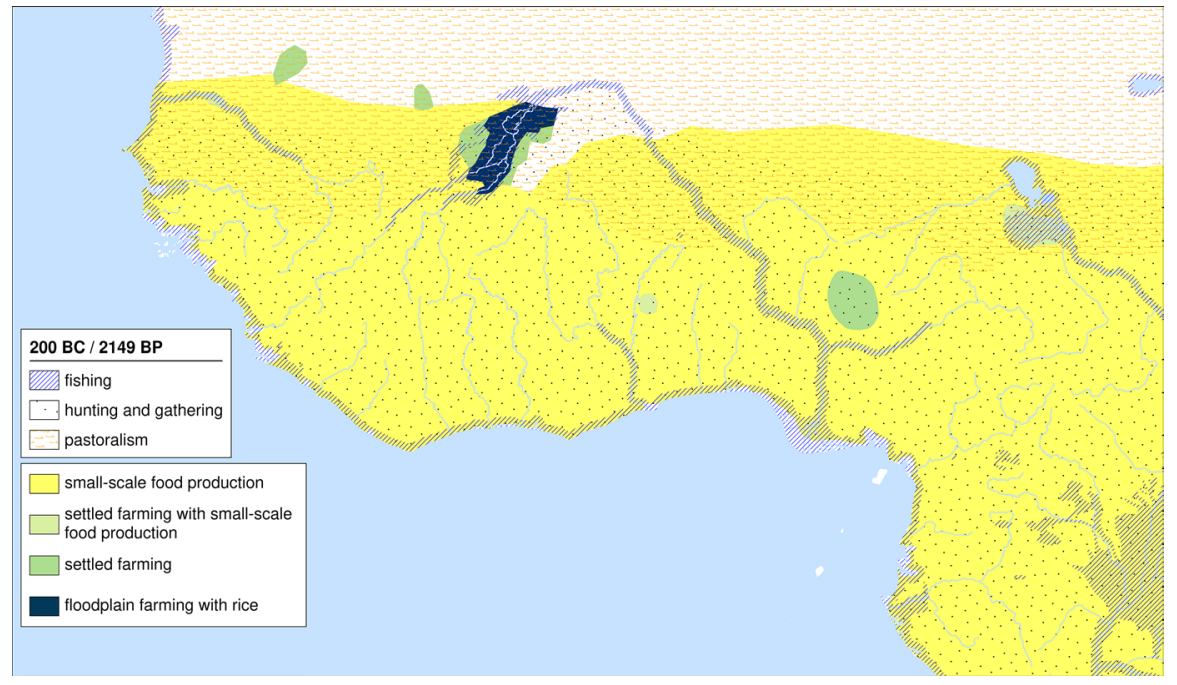

Fig. 10 Map of livelihood distributions in $200 \mathrm{BC}$

of the continent (Bostoen, Grollemund and Muluwa 2013; Grollemund et al. 2015; Russell, Silva and Steel 2014). Based on this evidence, we have extended the smallscale food-production polygon to include all of the Central African forests. We then extrapolate, based on the generally widespread use and long history of agriculture in the study area, that small-scale food production (at least) had also spread to the forests and coastal regions of West Africa. There is archaeological evidence of more settled farming and iron production at Dekpassanware (de Barros 2003, 2006).

In the Lake Chad Basin, the site of Kursakata had been reoccupied, and these Iron Age inhabitants relied heavily on cultivated pearl millet-in some layers $P$. glaucum represented $70 \%$ of the charred cereal remains - in addition to gathered wild grasses and fruits (Klee, Zach and Neumann 2000). At the nearby site of Mege, however, domesticated crops remained of minimal importance (Bigga and Kahlheber 2011). Interestingly, the animal remains show an opposite trend, with more wild resources, particularly fish, at Kurskata than at Mege, where there was a higher reliance on cattle (Linseele 2007).

Further west, this period saw the expansion of floodplain farming with rice in the Inner Niger Delta, and site abandonments on the Bandiagara plateau, but not on the adjacent Bandiagara cliffs (Garnier et al. 2015). There was a settlement and sedimentary hiatus at Ounjougou from approximately 300 BC to AD 300 (Ozainne, Lespez, Le Drezen et al. 2009). The city of Jenné-Jeno was in its earliest phases in this period (McIntosh and McIntosh 1981), but already covered 7 ha, and likely had an economy based on domesticated African rice, fishing, stock-keeping, and iron-working, though there are no ore sources in the region so raw materials would have been imported through trade (MacDonald 2013; R. J. McIntosh 1998). While this period saw the abandonment of many sites in southern Mauritania (the Dhars Tichitt-Walata having largely been abandoned), it also marks the Terminal Tichitt 
phase of the Tagant region, which is characterized by large stone-built compounds and the remains of iron-working (Kevin MacDonald pers. comm.; Ould Khattar 1995). The site of Waladé in the middle Senegal valley had developed into a more settled farming system with iron-working by this time; however, it was abandoned soon afterwards (Déme and McIntosh 2006).

\section{AD 200}

A major change following the $200 \mathrm{BC}$ time-window is the first mapped (Fig. 11) occurrence of diversified farming systems southwest of the Niger River, in what is now northern Benin and eastern Burkina Faso, as well as in northern-central Nigeria. Other changes include the expansion of settled farming between the Inland Niger Delta and the West Coast, and between central Nigeria and the southern Lake Chad Basin, as well as the extension of floodplain farming with rice down the Niger River as far as the modern border of Nigeria.

In northern Burkina Faso, large settlement mounds began to develop, occupied by iron-using farmers with a well-developed agricultural system (Höhn and Neumann 2012) and domestic stock-keeping, as well as some evidence for hunting and fishing (Linseele 2007). Oursi (Oursi 1 and Oursi West), for example, has evidence of diversified farming systems at this time (Kahlheber 2004). Sorghum (Sorghum bicolor), fonios/small millets (Digitaria or Brachiaria), and rice (Oryza glaberrima) were all recovered from the site of Birnin Lafiya dating to this time (Champion and Fuller 2018a; Haour, Nixon, Ndah, Magnavita and Smith 2016a), showing the presence in the region of both floodplain farming with rice and of diversified crop sets, and the faunal assemblage was dominated by fish throughout (Haour, Nixon, Ndah, Magnavita and Smith 2016b). Diversified farming is also present in the Nok region

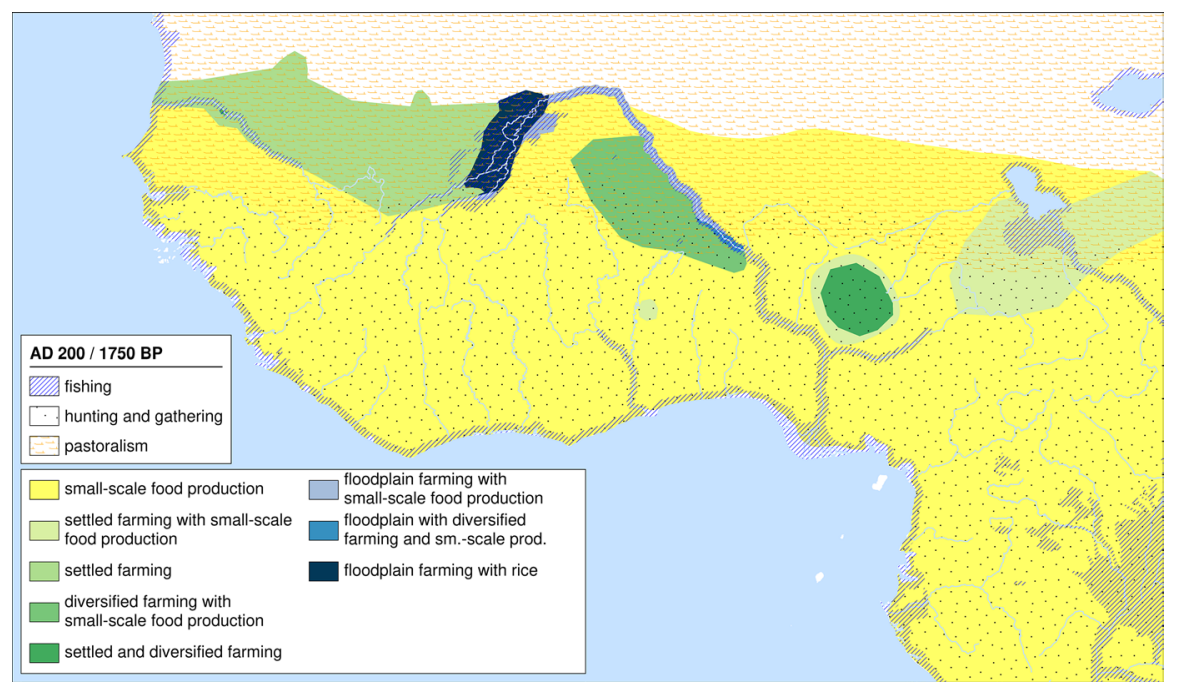

Fig. 11 Map of livelihood distributions in AD 200 
at this time (Höhn and Neumann 2016; Kahlheber, Höhn and Rapp 2009b), as well as further west, in the Middle Senegal Valley site of Cubalel (Murray, Fuller and Capezza 2007). The latter site had an agricultural system mainly based on the cultivation of pearl millet; however, fonio (Digitaria cf. exilis) had also been integrated into the crop set. This is the only evidence of diversified farming in the region by AD 200. At the same time, large settlement mounds began to develop in the Seno Plain, east of the Bandiagara Plateau in Mali (Huysecom, Ozainne et al. 2015).

Probably by this time, settled farming practices had become widespread in the semi-arid region between the Senegal River and the Inland Niger Delta. The density of farming activities in this region would have been highly dependent on annual moisture variability. Evidence of settled farming systems is found at sites on the periphery of the polygon, for example in the Terminal Tichitt phase of the Dhar Tagant (Kevin MacDonald pers. comm.; Ould Khattar 1995).

\section{AD 600}

By AD 600 (Fig. 12), diversified farming had expanded to a large portion of the Sahel, extending from the west side of the Inland Niger Delta to Lake Chad. Settled farming also expanded, extending to the coast in all but Central Africa, where there was a period of regional abandonment (Oslisly, Bentaleb et al. 2013a; Oslisly, White et al. 2013b). Also by this time, we estimate that floodplain farming with rice was present in the upper reaches of the Niger and Bani rivers, and their tributaries.

In the Lake Chad Basin, the first evidence of morphologically domesticated sorghum in the region is found in Mege (Bigga and Kahlheber 2011; Magnavita 2002), and the earliest evidence of cultural soil modification at Tiwa soon afterwards (Adderley et al. 2004). Alongside the expansion of diversified farming practices, the

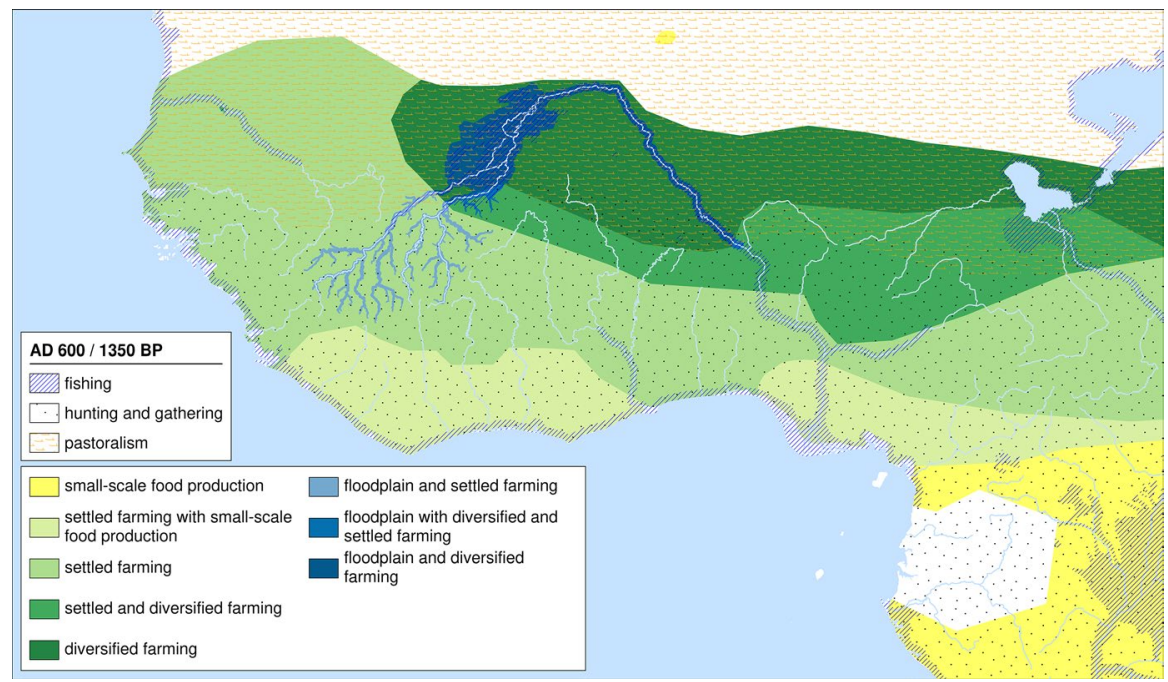

Fig. 12 Map of livelihood distributions in AD 600 
Blé Mound Complex in the Cameroonian Chad Basin contains evidence of specialized fishing activities beginning c. 250-500 AD and continuing in some capacity until c. 1400 AD (Holl 2002; Linseele 2007, 2017). Further south in Cameroon, the sites of Salak and Goray show evidence of a diversified system of two varieties of sorghum (S. caudatum and durra) combined with arboriculture (Delneuf 1998; Otto 1998).

Additional evidence of sorghum has been found in the archaeobotanical assemblages of sites such as Dia Shoma (Fuller and Stevens 2018), Jenné-Jeno (Fuller and Stevens 2018), and Birnin Lafiya (Champion and Fuller 2018a; Fuller and Stevens 2018; Haour et al. 2016a). These finds are the earliest regional evidence of a diversification of the farming system. Further west, the Middle Senegal Valley site of Sincu Bara (Murray 2008) still had an agricultural system mainly based on the cultivation of pearl millet, and supplemented by gathering wild species. Linguistic analysis indicates that the cultivation of African rice was practiced in the Mande heartland of the Guinea Highlands by at least this time (Carney 2001). Therefore, for this timewindow we have extended the polygon representing floodplain farming with rice up the Niger and Bani Rivers and their major tributaries. It is also around AD 600 that the site of Essouk-Tadmakka, in the far northern arid Sahel, was first occupied on a semi-permanent basis. The site was an early trans-Saharan trade center and the inhabitants were likely cultivating pearl millet and various legumes on a small scale in this phase (Nixon, Murray and Fuller 2011).

\section{AD 1100}

One major change following the AD 600 time-window is the expansion of rice-based agriculture in the west. This includes the first mosaic of paddy rice and floodplain

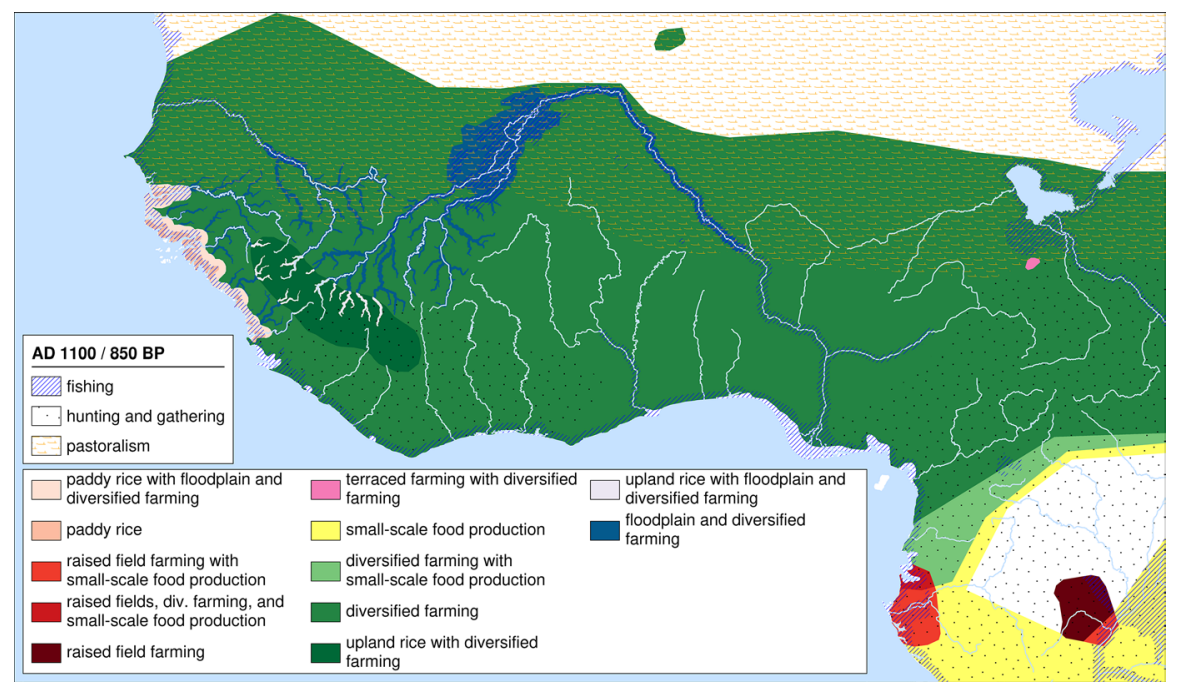

Fig. 13 Map of livelihood distributions in AD 1100 
farming with rice along the west coast and upper Senegal River, and the first upland rice-farming systems in the Guinea highlands. Another major change is the expansion of diversified farming systems to the majority of the map (Fig. 13), including coastal West Africa and the northern and coastal parts of the Central African forests. This map also shows the first instances of terrace farming and raised-field farming. Despite the broad expansion of agricultural practices by this time, there is also an extensive period of abandonment of small-scale food production sites documented in the inland portion of the Central African forests (Morin-Rivat, Biwole et al. 2016; Morin-Rivat, Fayolle et al. 2014).

The expansion of rice cultivation to the west coast, Senegal River, and Guinea highlands by this time is based on linguistic analysis (Carney 2001). Linguistic evidence specifically indicates the development of coastal mangrove rice-farming systems in the Rio Nunez region on the northern coast of Guinea between approximately AD 500 and 1000, so it would have been well established by this time-window (Fields-Black 2008a, b). It then follows that the mosaic of paddy rice, floodplain farming, and upland rice systems must have been established in the region by this time. Many sites along the Niger River in Benin, including Pekinga, Tintin, Birnin Lafiya, Kantoro, Guene Zeno, and Madekali Road, contained evidence of both African rice from floodplain farming and diversified rain-fed systems dating to this time-window (Champion and Fuller 2018a, b).

There was also an expansion of diversified farming systems at this time. Evidence from two Volta Phase sites (c. AD 1000-1280) in western-central Ghana (Banda 13 and 27) shows that sorghum had been incorporated into the regional crop-set by that time, though pearl millet still dominated the assemblages (Logan 2012). At Sadia, in the Seno Plain of Mali, there is evidence for the presence of a typical SudanoSahelian agroforestry system with mixed cropping and interspersed useful trees (Huysecom, Ozainne et al. 2015). The site Saouga in Burkina Faso also offers evidence for agroforestry at this time (Neumann, Kahlheber and Uebel 1998). Further north, the site of Essouk-Tadmakka had become an important and permanently occupied trans-Saharan trading entrepôt. Both faunal and archaeobotanical evidence point to a diversification of the economy, including the addition of wheat (Triticum aestivum, T. durum) and cotton (Gossypium sp.) to the crop-set (Nixon, Murray and Fuller 2011). Camel (Camelus dromedarius), chicken (Gallus gallus), and cattle (Bos sp.) were present in a faunal assemblage consisting of mainly caprines (Nixon 2009). Tegdaoust (Awdaghust) in southern Mauritania is mentioned in several early Arabic sources, the most detailed of which is al-Bakri's Book of Roads and Kingdoms, written in the mid eleventh century, probably using al-Warraq's midtenth century work as a source (Levtzion and Hopkins 1981). Al-Bakri describes a vibrant and prosperous market city, with both imported and locally grown crops, and economic stratification (rich, poor, and slaves). He specifically mentions that dates, wheat, cucumbers, figs, vines, and henna were grown around the city; sorghum was eaten by the poorer classes and so was probably grown locally. The inhabitants also ate various imported goods, depending on their economic status, including honey from the south, and dates, raisins, and wheat from the trans-Saharan north. In addition to the crops, there would have been many camels used for the trans-Saharan trade, and he mentions that sheep and cattle were abundant and cheaply purchased. 
While historic records using colloquial names can be problematic for species identification, the description clearly indicates a diversified system. The Almoravid raid of AD 1054/1055 likely impacted the affluence of the city and necessitated a rebuilding phase (Robert 1970), but its continued occupation is documented archaeologically until a marked decline began at the end of the twelfth century and extended until eventual abandonment in the fourteenth century (McDougall 1985). Further east, in the Lake Chad Basin, the site of Mege had also fully adopted a diversified farming system. The archaeobotanical assemblage during this period displays a shift to a higher dependence on domesticates generally, with the important addition of cowpea, bottle gourd (Lagenaria siceraria), and high percentages of cotton (Gossypium sp.) (Bigga and Kahlheber 2011). There were also increased counts of the already-present domesticates: sorghum, okra, and pearl millet.

Lastly, two new categories are added to the map by this time: terrace farming and raised-field farming. In the Mandara Mountains of northern Cameroon, a date from the site of Ngoye Kirawa provides a terminus post quem of c. AD 780-1020 (TO-4425, $1120 \pm 50 \mathrm{BP}$ ) for the construction of agricultural terraces at that site, and is the earliest date in the region for this type of agriculture (MacEachern 2012a). Further south in coastal Gabon, a trench in a raised field has been dated to approximately AD 750 (1200 BP), indicating the establishment of this type of farming by at least this time-window (Richard Oslisly pers. comm. 2017).

\section{AD 1500}

Major changes following the AD 1100 time-window include the reoccupation of the Central African forests, the extension of diversified farming practices to that region, the expansion of rice-farming systems in the west, but the retreat of floodplain farming with rice up the Niger River as far as Gao. This was a period of abandonment of major farming sites on both sides of the middle Niger River and south of the Niger River bend, possibly due to a severe drought that occurred in the region just prior to this time-window (Maley and Vernet 2015), but also corresponding to the expansion of the Songhai empire (Albert, Hallier, Kahlheber and Pelzer 2000). In the Seno Plain (Mali), climatic-environmental degradation cannot be considered as a main causal factor of the abandonment of settlement mounds around the fourteenth century AD (Huysecom, Ozainne et al. 2015). South of Lake Chad, this map (Fig. 14) shows the expansion of terrace farming in the highlands, and the first occurrence of Masakwa farming in the firgi plains. Portuguese explorers had documented the coast of West, Central, and South Africa, including rounding the Cape of Good Hope. The Portuguese constructed a fortress, Elmina Castle, on the coast of Ghana in 1482, and European trade goods became common at many sites in the region soon afterwards (Logan 2012). The maps, therefore, reflect indigenous agricultural developments, as the introduction of 'New World' crops can only have occurred in the following century.

By AD 1500, there were well-established and sophisticated rice cultivation systems throughout West Africa. Early European explorers wrote detailed descriptions of the vegetation, foods, people and agricultural systems along the West African coasts and major rivers, with specific coastal extents mentioned: grains were grown 


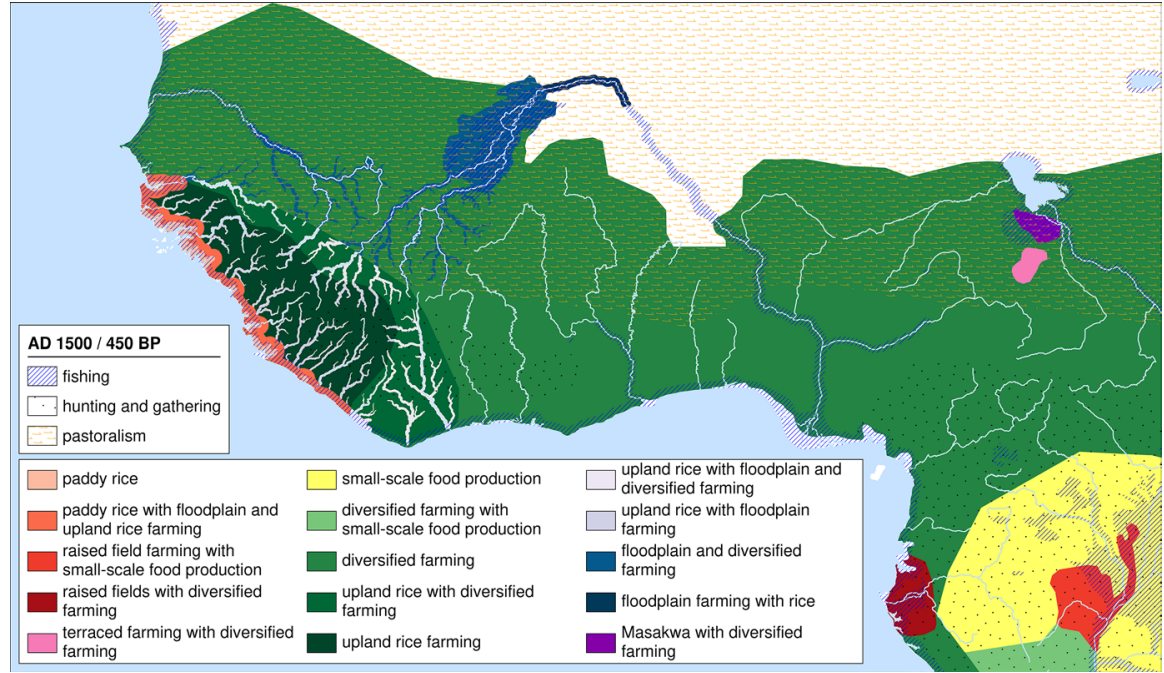

Fig. 14 Map of livelihood distributions in AD 1500

south of the Senegal River as far east as Liberia, where yams and other root crops became more abundant (Carney 2001). South of the Gambia River, along the coast to Buchanan in Liberia, rice was the dominant crop. In addition to the mosaic of coastal 'mangrove' rice paddies and floodplain farming with rice, farmers in this region utilized the landscape gradient to plant and harvest as many as three fields of rice in a single season: one in the wetlands, one slightly higher, and one in the uplands. The three rice crops would ripen at different times making them more convenient to harvest. To reflect this, the maps show a mosaic of paddy rice, floodplain farming, and upland rice farming.

In the Lake Chad Basin, the technique known as Masakwa had likely been established by this time. This system, which involves trapping floodwaters behind small dikes in order to cultivate a dry-season crop of sorghum, is mentioned by the Arab chronicler Ibn Furtu in his account of a siege in c. 1575 (Gronenborn 2001). While this reference is slightly later than the specific time-window in question, it seems likely that the technique was established prior to its first historic mention (Bigga and Kahlheber 2011). Further south, in the Mandara Mountains, this period marks the height of a series of monumental, stone-built, chiefly centers called the diy-geä-bay or DGB sites (see Fig. 5) and the likely expansion of the agricultural terrace systems in the region (MacEachern 2012a, b; MacEachern, Djoussou and Janson 2010). This type of terraced-farming system grew in importance and appeared in other areas of the continent in the following centuries (Grove and Sutton 1989; Stump 2010; Widgren 2000, 2010), and is still an important feature of the Mandara landscape today.

South of the Niger River, from the southern part of central Mali (Bandiagara Escarpment) to the southern side of the river in Burkina Faso and northern Benin, large agricultural sites were abandoned around this time. Additionally, there was a 
retraction of floodplain farming with rice up the Niger River as far as Gao. However, some diversified farming sites along the Niger River in Northern Benin continued to be occupied: Kozungu S1, Bogo-bogo, and Madekali. At these sites, the presence of cereals such as pearl millet decreased and African rice disappeared, but evidence for the utilization of trees like baobab (Adansonia digitata) and oil palm increased, in parallel with the utilization of cotton (Champion and Fuller 2018a, b). Some of these tree products may have been traded to these sites from the south as the local economy increased production of cotton for export (Champion and Fuller 2018b). This era in general may have seen increasing trade in foodstuffs over longer distances.

The large trans-Saharan entrepôts of Tegdaoust and Essouk-Tadmakka had both been abandoned by this time; however, the historic city of Timbuktu, founded by the Tuareg around the twelfth century AD, had grown into a wealthy urban center (Insoll 2002; Post Park 2009, 2011), and historic sources suggest that smaller agricultural settlements in the western Sahel persisted (Webb 1995). Further south, in the Banda region of Ghana, sites such as Kuulo Kataa and Ngre Kataa contain evidence of the continued reliance on diversified crops during the Ngre and Kuulo periods. The large faunal dataset from these sites contained mostly wild animals with only a few definitively domestic animals included in the assemblage (Logan 2012). Even further south, this area of diversified farming supported many different types of settlement type and population density, from dispersed rural farming villages to large urban centers along established trade routes. Some of these larger sites, such as Begho, Benin, Ile-Ife, and Oyo-Ile, were not only trading centers but also sociopolitical hubs with control over extensive hinterlands (Ogundiran 2013).

\section{Discussion}

To avoid falling back on models of social evolution or frameworks developed for other regions, we categorized land-use practices based on local archaeological knowledge in a simplified way that can be integrated into large-scale studies on land-use change (e.g. Morrison, Gaillard, Madella, Whitehouse, and Hammer 2016). We mapped the resulting categories as geographically continuous polygons for nine time-windows covering the period $1800 \mathrm{BC}-\mathrm{AD}$ 1500. These maps represent the distribution of livelihoods and therefore land-use systems in western Africa at a critical period in the environmental history of the region. The overall trend in changes in land use in western Africa over our period of interest is that of discontinuous and finite bouts of initial agricultural exploitation until the adoption of more diversified and/or intensive systems, which in most cases increased the stability of, and human dependence on, agricultural production. However, even after the adoption of more diversified systems, there are still regional instances of the abandonment of large sites and agricultural strategies. In some cases, this may have been due to regional political shifts or large-scale disease outbreaks; in others, it might be associated with environmental change, either exogenous, such as drought, or endogenous, such as anthropogenic soil erosion. 
Both small-scale food production and settled farming are present by the first (1800 BC) time-window, but in discontinuous and limited regions. By $200 \mathrm{BC}$, small-scale food production had expanded to the entire study region, and by AD 600 , more intensive, diverse, and sedentary settled farming was the primary form of land use across western Africa. Rice agriculture first appears on the maps in 600 BC in the form of floodplain farming with rice, and by AD 1100 had spread from the middle Niger River to the Guinean coast in the form of paddy rice, and the Guinea Highlands in the form of upland rice. Diversified farming systems first appear in AD 200, and are the predominant form of land use across the region by AD 1100 . The most intensive systems do not appear until the last two time-windows: paddy rice farming, raised-field farming, and terraced farming by AD 1100, and Masakwa farming by AD 1500 .

When evidence of absence was available, in the form of regional abandonments or the end of particular cultural complexes, those areas were mapped. For example, the end of the Kintampo culture is represented by the absence of small-scale food production in central Ghana on the $1000 \mathrm{BC}$ map. It has been conjectured that the Kintampo complex may have been affected by climate changes. An onset of seasonality and a distinct dry season c. 1250 BC (3200 cal. BP) likely reduced forest cover and affected the oil palms, on which the Kintampo relied heavily (Logan and D'Andrea 2012).

Settlement pattern shifts in the Dhars of southern Mauritania are represented by a fragmentation of the settled farming polygons on the $600 \mathrm{BC}$ map. This pattern has been attributed to attacks by the more technologically advanced Berbers (MacDonald 2013; Munson 1980). The few survivors of these attacks retreated to small fortified settlements.

The abandonment of sites on the Bandiagara Plateau is shown on the $200 \mathrm{BC}$ map. The sedimentary hiatus at Ounjougou is attributed to a period of drought, which may have triggered technological, cultural, and settlement pattern changes in the region (Ozainne, Lespez, Le Drezen et al. 2009). Two separate episodes of abandonment are shown in the central African forests. The first centered in northern Gabon, extending to some coastal areas around AD 600 (Oslisly, White et al. 2013b), and then further inland in the western Congo Basin, represented on the map of AD 1100 (Morin-Rivat, Fayolle et al. 2014). These two periods of contraction may be part of the same pattern of waves of expansion through the forest (MorinRivat, Fayolle et al. 2014). Other suggested causes of this pattern include climate changes and episodes of pandemic diseases such as trypanosomiasis or even Ebola (Oslisly, White et al. 2013b; Wotzka 2006).

Finally, the abandonment of agricultural sites along the Niger River in large portions of Mali, Burkina Faso, Niger, and northern Benin is shown on the map of AD 1500. While Maley and Vernet (2015) have reported that climatic instabilities led to unstable flow levels in the Middle Niger River from the eighth to fifteenth centuries, and large fluctuations in the Inland Niger Delta, they suggest that these had significant consequences for regional populations and political bodies in the thirteenth to sixteenth centuries. However, Huysecom, Ozainne et al. (2015) do not believe that environmental factors can be blamed for the abandonment of Seno Plain sites in the fourteenth century, and changing socio-political and economic circumstances may 
have played a larger role in some areas (Albert et al. 2000; Champion and Fuller 2018b).

\section{Uncertainties}

Our land-use maps were developed largely on the basis of published site- and regional-level archaeological investigations. As noted above, excellent work has been done at individual sites, but generalization to the entirety of western Africa is problematic because of low site density in many regions. Because of the spatially and temporally discontinuous nature of the source data, direct interpolation between sites was not a practical option. In some cases, historic accounts or expert regional knowledge were used to fill the gaps in the archaeological site data; in other areas conservative extrapolation was employed. This is not an issue exclusive to our project area, and these types of large data gaps are common across sub-Saharan Africa (Lane 2015).

Archaeobotanical analyses, when available, were the most valuable source of data to inform our land-use classification and mapping. Unfortunately, the use of flotation and other archaeobotanical sampling techniques is a relatively recent practice, and is still not standard on many excavations. Only $23 \%$ of the sites in our database $(n=425)$ have associated archaeobotanical results. Other types of data collected that are indicative of land use include: faunal remains, present at $7 \%$ of sites $(n=131)$; presence of metallurgy or other technological indicators; soil charcoal, indicative of burning frequency. General notes about the type of site can also give clues as to land use. Many archaeological publications focus on ceramic styles or architecture, which are less reliable sources of information concerning livelihood, but can indicate degrees of sedentism or cultural affiliation to other sites. We have provided a list of archaeological sites with coordinates, references, and associated data types in Appendix A (Table 2) (online supplementary material).

Further uncertainty is present in the source data due to the fact that a major radiocarbon calibration plateau falls within our period of interest (Hajdas 2008), and to the large standard error ranges in many of the older dates. While Bayesian agedepth models can be used to reduce the uncertainty associated with flat sections in the calibration curve (Steier and Rom 2000; Steier, Rom and Puchegger 2001), few archaeological sites in western Africa have been sampled at sufficient resolution to make this a viable solution for large regional-scale studies. Finally, many of the sites in the database are not radiometrically dated: only $61 \%(n=1126)$ have at least one radiocarbon or thermoluminescence date $(n=3734)$. The remaining sites have been assigned to a general period, culture, or technological tradition for which a regional date range is known.

The numbers of sites with archaeobotanical analysis or radiocarbon dates are not the only uncertainties associated with the archaeological distribution; the spatial coverage of archaeological studies has been greatly affected by modern socio-political boundaries. Particularly poorly-represented archaeologically is the southwest 
portion of our study area (see Fig. 2). Our database contains only 44 archaeological sites in Guinea $(n=1)$, Guinea-Bissau $(n=0)$, Sierra Leone $(n=3)$, Liberia $(n=16)$, and Côte d'Ivoire $(n=24)$ combined. The sites in Côte d'Ivoire are either along the coast, or clustered far inland towards the borders with Mali and Burkina Faso. This leaves a broad swath of territory, from eastern Côte d'Ivoire at the Ghana border to the coast of Guinea-Bissau, that is unrepresented in the archaeological data. Furthermore, with the exception of recent work in the far northwest and far southeast of Côte d'Ivoire (Huysecom, Mayor et al. 2016; Serneels et al. 2015), all the sites in those countries were documented in the late 1960s and 1970s and contain limited information about subsistence or land-use practices (e.g. Gabel 1976). To promote data transparency, we produced a series of data-density maps showing the data distribution for each time-window. These 'heatmaps' are provided in Online Appendix B (Figures 15-23), and show both the locations of point-based archaeological radiocarbon and archaeobotanical data at each time-window, as well as an approximation of data-density based on radiocarbon, but not the occurrences of regional historical descriptions. The maps were normalized relative to the highest value in the density kernel across all of the time-slice maps for easier comparison.

In order to compensate for these archaeological data gaps, we have used historical sources and linguistic analyses where possible. These types of sources have their own inherent uncertainties, and are not easily translated into a data point. Therefore, historic landscape and subsistence descriptions, and crop-origin regions based on linguistic analysis, are not included on the data-coverage map in Fig. 2. While the precise locations of these places are harder to know based on a historic description, the description of land use is more detailed than what can usually be gleaned from archaeological data-for example, the three-field rice-farming strategy described for the AD 1500 map (see Carney 2001 for a summary of historic descriptions of the 'rice coast').

As with all research, accuracy is a moving target, and as archaeological work continues in the region and additional data are published, the maps may be revised. New field data will ultimately be required in key, unexplored regions to see whether newly excavated sites fit the extrapolated trends in our maps, or if they add completely new information. For example, the origin and distribution patterns of types of rice farming will likely be affected by analysis currently being carried out on material from key areas (e.g. the Seno Plain of Mali), and by any future work in the Guinea Highlands. Therefore, the ensuing map-set is the result of a combination of data sources and interpretations, which represents a consensus hypothesis for the generalization of the limited and localized information currently available in the region.

\section{Applications and Outlook}

The maps we present here, in addition to being a stand-alone synthesis of developments in the agricultural livelihoods of western Africa, can be used to better understand the relationship of humans to their environment over the longue durée. The polygon maps (Figs. 6, 7, 8, 9, 10, 11, 12, 13, 14) will be valuable for qualitative 
comparison with other archaeological and palaeoenvironmental archives and as inputs to quantitative models of coupled human and natural systems. The maps, and their associated uncertainties (supplemental Figures 15-23), provide a valuable basis for guiding future research efforts. In certain regions and periods, we map important land-use changes, but with very little hard data behind them. Thus, the polygon maps provide a rationale for guiding future field data collection efforts, both in the form of new excavations and revisiting of known sites with a focus on under-investigated periods.

Our maps could be employed in the evaluation of pollen-based land-cover reconstructions, either site-based or large-scale reconstructions, with human land use and its possible influence on vegetation. Well-preserved pollen archives are rarely found in close proximity to archaeological sites-because pollen archives tend to be at the bottom of perennial lakes-and are thus difficult to compare directly with point-based archaeological data, as has also been shown recently for East Africa (Marchant et al. 2018). A notable exception is the work under way at Lake Barombi Mbo in Cameroon (Garcin, Deschamps et al. 2018a; Garcin, Schefuß et al. 2014), where the ideal combination of a small watershed and lakeside archaeological sites is showing promising results in terms of delineating human versus natural drivers of vegetation change in the catchment, and generating new controversies (Clist et al. 2018; Garcin, Deschamps et al. 2018b, c; Giresse et al. 2018). Our maps provide a spatially continuous dataset that can be compared with pollen and other environmental archives throughout the study area.

The category definitions and maps presented here also provide valuable information on land use that can be used to move beyond the current generation of global anthropogenic land-cover-change scenarios, such as KK10 and HYDE (Kaplan, Krumhardt et al. 2010). These widely-used scenarios rely on population estimates and simple estimates of per-capita land use to quantify anthropogenic land-cover change-often equated with deforestation-over time. In considering the broad range of land uses present in western Africa in the prehistoric and precolonial past, and demonstrating how these change over time, our categories and maps challenge the simplistic idea that anthropogenic land-cover change can be modeled as a simple function of population, and highlight the need to account for land-use change that is frequently both nonlinear and uncoupled from the properties of the physical environment. Our maps thus provide invaluable information on the otherwise unpredictable sociocultural attributes of land use that will inform new continental to global models of past anthropogenic land-cover change.

Using a combination of the sociocultural information provided in our categories and maps and the work of others (see e.g. Widgren 2010), along with reconstructions of the physical environment, new models may even provide an opportunity to remove a reliance on often-problematic palaeodemographic estimates in favor of a carrying-capacity approach where a forward demographic model is driven by the constraints imposed upon it by subsistence livelihood and the environment. These models will be developed in the coming years and ultimately demonstrate the value of our mapping approach for a wide range of applications. 
Future work towards building a more complete atlas of human influence should focus on incorporating additional layers: iron-working intensity estimates, domesticated-species distributions, political regions of influence, urban centers, population density, and industrial extraction and production areas. These layers could further influence the physical expression of the land-use types presented here. While the land-use maps presented here show the range of distribution of individual livelihood categories, and each of those categories has an associated environmentally constrained carrying capacity, the population within each polygon would be unlikely to be evenly distributed throughout that polygon. Human populations tend to cluster in some areas and disperse in others, and these patterns have different and measurable effects on the local landscape (Feinman 2015; Kirleis, Marinova, Valamoti, Dreibrodt and Heiss. 2017). Therefore, the physical expression of land use (in a modeling environment, for example) would need to be modulated by separate layers of population density distribution. This could be based partially on our database of archaeological site distributions, combined with a database of urban centers compiled based on several palaeodemographic syntheses.

\section{Conclusion}

This study represents a first step in a novel technique for conceptualizing past livelihoods, mapping past agricultural land-use distributions, and building products for the quantitative modeling of human-environment interactions. This kind of synthesis will be very valuable for future interdisciplinary research and studies over large time and geographic scales. The atlas covers an important transitional period in West African history; the early maps are dominated by hunting and gathering with only isolated areas of farming, and by the end of the series the opposite is true. However, the transition is not always geographically or temporally linear, and periods of abandonment are also apparent.

The atlas provides a spatialized synthesis of West African land-use history that can also be used as a base for comparison in other interdisciplinary studies of climate change, environmental transformation, palaeodemography, settlement-pattern changes, and quantitative models of human-environment interaction. While this study draws on several previous regional syntheses, it is the first temporally resolved and spatially continuous visualization of agricultural developments in western Africa, and is designed to form an essential basis for future studies of human-environment interaction in the region.

Acknowledgements Open access funding provided by Max Planck Society. This work was supported by Grants to JOK from the European Research Council (COEVOLVE, 313797), the Swiss National Science Foundation (ACACIA, CR10I2_146314), and the Fondation Herbette (2016-2-E-16). JMR was funded by the Funds for Research Training in Industry and Agriculture (National Funds for Scientific Research, Belgium) and the Leopold II Funds (Belgium). Data were also acquired in the framework of the Era-Net BiodivERsA CoForChange project, funded by the French National Research Agency and National Environment Research Council (UK). We thank Mats Widgren and the other participants of the 2015 PAGES and SNSF (IZ32Z0_164147) supported workshop Mapping Land Use and Subsistence in West Africa, which led to this paper; Kathy Morrison and other members of LandUse6k for their input on category nomenclature; Richard Oslisly for his input on raised field systems; and Kevin MacDonald for advice about the 
settlement history of southern Mauritania and western Mali. We also thank two anonymous reviewers whose detailed comments made this paper stronger. This article is a contribution to the PAGES LandCover6k working group and the Integrated History and Future of People on Earth (IHOPE) Initiative.

Open Access This article is distributed under the terms of the Creative Commons Attribution 4.0 International License (http://creativecommons.org/licenses/by/4.0/), which permits unrestricted use, distribution, and reproduction in any medium, provided you give appropriate credit to the original author(s) and the source, provide a link to the Creative Commons license, and indicate if changes were made.

\section{References}

Adderley, W. P., Simpson, I. A., Kirscht, H., Adam, M., Spencer, J. Q., \& Sanderson, D. C. W. (2004). Enhancing ethno-pedology: Integrated approaches to Kanuri and Shuwa Arab definitions in the Kala-Balge region, northeast Nigeria. CATENA, 58(1), 41-64.

Albert, K.-D., Hallier, M., Kahlheber, S., \& Pelzer, C. (2000). Montée et abandon des collines d'occupation de l'âge de fer au Nord du Burkina Faso. Berichte des Sonderforschungsbereichs, 268(14), 335-351.

Aleman, J. C., Blarquez, O., \& Staver, C. A. (2016). Land-use change outweighs projected effects of changing rainfall on tree cover in sub-Saharan Africa. Global Change Biology, 22(9), 3013-3025.

Archibald, S., Staver, A. C., \& Levin, S. A. (2012). Evolution of human-driven fire regimes in Africa. Proceedings of the National Academy of Sciences of the United States of America, 109(3), 847-852.

Armitage, S. J., Bristow, C. S., \& Drake, N. A. (2015). West African monsoon dynamics inferred from abrupt fluctuations of Lake Mega-Chad. Proceedings of the National Academy of Sciences of the United States of America, 112(28), 8543-8548.

Assi-Kaudjhis, C., Digbehi, B. Z., Roche, E., \& Lezine, A.-M. (2010). Synthèse sur l'évolution des paléoenvironnements de l'Afrique occidentale atlantique depuis la fin de la dernière période glaciaire: Influences climatiques et anthropiques. Revue internationale de géologie, de géographie et d'écologie tropicales, 34, 1-28.

Backes, M. M. (2001). The role of indigenous trees for the conservation of biocultural diversity in traditional agroforestry land use systems: The Bungoma case study. In situ conservation of indigenous tree species. Agroforestry Systems, 52, 119-132.

Battistel, D., Argiriadis, E., Kehrwald, N., Spigariol, M., Russell, J. M., \& Barbante, C. (2017). Fire and human record at Lake Victoria, East Africa, during the Early Iron Age: Did humans or climate cause massive ecosystem changes? The Holocene, 27(7), 997-1007.

Bayon, G., Dennielou, B., Etoubleau, J., Ponzevera, E., Toucanne, S., \& Bermell, S. (2012a). Intensifying weathering and land use in Iron Age Central Africa. Science, 335(6073), 1219-1222.

Bayon, G., Dennielou, B., Etoubleau, J., Ponzevera, E., Toucanne, S., \& Bermell, S. (2012b). Response to comments on 'Intensifying weathering and land use in Iron Age Central Africa'. Science, 337(6098), 1040.

Bedaux, R., MacDonald, K., Person, A., Polet, J., Sanogo, K., Schmidt, A., et al. (2001). Dia archaeological project: Rescuing cultural heritage in the Inland Niger Delta (Mali). Antiquity, 75(290), 837-848.

Bezançon, G. (1995). Riziculture traditionnelle en Afrique de l'Ouest: Valorisation et conservation des ressources génétiques. Journal d'agriculture traditionnelle et de botanique appliquée, 37(2), 3-24.

Bigga, G., \& Kahlheber, S. (2011). From gathering to agricultural intensification: Archaeobotanical remains from Mege, Chad Basin, NE Nigeria. In A. G. Fahmy, S. Kahlheber \& A. C. D'Andrea (Eds.), Windows on the African past: Current approaches to African archaeobotany. Reports in African Archaeology, vol 3: Proceedings of the 6th International Workshop on African Archaeobotany, Cairo (pp. 19-65). Frankfurt am Main: Africa Magna Verlag.

Binford, L. R. (2001). Constructing frames of reference: An analytical method for archaeological theory building using ethnographic and environmental data sets. Berkeley: University of California Press. 
Boivin, N. L., Zeder, M. A., Fuller, D. Q., Crowther, A., Larson, G., Erlandson, J. M., et al. (2016). Ecological consequences of human niche construction: Examining long-term anthropogenic shaping of global species distributions. Proceedings of the National Academy of Sciences of the United States of America, 113(23), 6388-6396.

Bostoen, K., Clist, B., Doumenge, C., Grollemund, R., Hombert, J.-M., Muluwa, J. K., et al. (2015). Middle to Late Holocene paleoclimatic change and the early Bantu Expansion in the rain forests of western Central Africa. Current Anthropology, 56(3), 354-384.

Bostoen, K., Grollemund, R., \& Muluwa, J. K. (2013). Climate-induced vegetation dynamics and the Bantu Expansion: Evidence from Bantu names for pioneer trees (Elaeis guineensis, Canarium schweinfurthii, and Musanga cecropioides). Comptes Rendus Geoscience, 345, 336-349.

Braje, T. J., \& Erlandson, J. M. (2013). Human acceleration of animal and plant extinctions: A Late Pleistocene, Holocene, and Anthropocene continuum. Anthropocene, 4, 14-23.

Breunig, P. (2013). Pathways to food production in the Sahel. In P. Mitchell \& P. Lane (Eds.), The Oxford handbook of African archaeology (pp. 555-570). Oxford: Oxford University Press.

Breunig, P., \& Neumann, K. (2002). Continuity or discontinuity? The 1st millennium BC crisis in West African prehistory. In T. Lenssen-Erz et al. (Eds.), Tides of the desert/Gezeiten der wïste: Contributions to the archaeology and environmental history of Africa in honour of Rudolph Kuper. Africa Praehistorica (Vol. 14, pp. 491-505). Köln: Heinrich-Barth-Institut.

Brierley, C., Manning, K., \& Maslin, M. (2018). Pastoralism may have delayed the end of the green Sahara. Nature Communications, 9(1), 4018.

Bronk Ramsey, C. (2009). Bayesian analysis of radiocarbon dates. Radiocarbon, 51(1), 337-360.

Brunk, K., \& Gronenborn, D. (2004). Floods, droughts, and migrations: The effects of Late Holocene lake level oscillations and climate fluctuations on the settlement and political history in the Chad Basin. In M. Krings \& E. Platte (Eds.), Living with the lake: Perspectives on history, culture and economy of Lake Chad. Studien Zur Kulturkunde (pp. 101-132). Köln: Rüdiger Köppe Verlag.

Butzer, K. W. (1996). Ecology in the long view: Settlement histories, agrosystemic strategies, and ecological performance. Journal of Field Archaeology, 23(2), 141-150.

Carney, J. A. (2001). Black rice: The African origins of rice cultivation in the Americas. Cambridge: Harvard University Press.

Casey, J. (2013). The Stone to Metal Age in West Africa. In P. Mitchell \& P. Lane (Eds.), The Oxford handbook of African archaeology (pp. 603-614). Oxford: Oxford University Press.

Casey, J., Sawatzky, R., Godfrey-Smith, D. I., Quickert, N., D’Andrea, A. C., Wollstonecroft, M., et al. (1997). Report of investigations at the Birimi site in northern Ghana. Nyame Akuma, 48, 32-38.

Catling, D. (1992). Rice in deep water. London: Macmillan.

Champion, L., \& Fuller, D. Q. (2018a). Archaeobotanical analysis: Agricultural diversification and change in the Niger Valley. In A. Haour (Ed.), Two thousand years in Dendi, Northern Benin: Archaeology, history and memory. Journal of African Archaeology Monograph series (Vol. 13, pp. 216-234). Leiden: BRILL.

Champion, L., \& Fuller, D. Q. (2018b). New evidence on the development of millet and rice economies in the Niger River Basin: Archaeobotanical results from Benin. In A. Mercuri, C. D’Andrea, R. Fornaciari, \& A. Höhn (Eds.), Plants and people in the African past: Progress in African archaeobotany (pp. 529-547). New York: Springer.

Ciampalini, R., Billi, P., Ferrari, G., Borselli, L., \& Follain, S. (2012). Soil erosion induced by land use changes as determined by plough marks and field evidence in the Aksum area (Ethiopia). Agriculture, Ecosystems \& Environment, 146(1), 197-208.

Clist, B., Bostoen, K., de Maret, P., Eggert, M. K. H., Höhn, A., Mbida Mindzie, C., et al. (2018). Did human activity really trigger the late Holocene rainforest crisis in Central Africa? Proceedings of the National Academy of Sciences of the United States of America, 115(21), E4733-E4734.

Contreras, D. A. (2016). Correlation is not enough: Building better arguments in the archaeology of human-environment interactions. In D. A. Contreras (Ed.), The archaeology of human-environment interactions: Strategies for investigating anthropogenic landscapes, dynamic environments, and climate change in the human past (pp. 3-22). London: Routledge.

Cook, H. (2000). The fish bones from Gadei. In T. Insoll (Ed.), Urbanism, archaeology, and trade: Further observations on the Gao region (Mali). The 1996 field season results. BAR International Series (Vol. 829, pp. 38-55). Oxford: Archaeopress.

D'Andrea, A. C., \& Casey, J. (2002). Pearl millet and Kintampo subsistence. African Archaeological Review, 19(3), 147-173. 
D’Andrea, A. C., Logan, A. L., \& Watson, D. J. (2006). Oil palm and prehistoric subsistence in tropical West Africa. Journal of African Archaeology, 4(2), 195-222.

Davies, O. (1967). West Africa before the Europeans: Archaeology and prehistory. Methuen's handbooks of archaeology. London: Methuen.

de Barros, P. (2003). Recent early Iron Age research in Bassar, Togo. Nyame Akuma, 59, 76-78.

de Barros, P. (2006). Dekpassanware: Early Iron Age site in the Bassar region of northern Togo. Paper presented at the 18th Biannual Meeting of the Society for Africanist Archaeologists, Calgary, October 20, 2006

De Brue, H., \& Verstraeten, G. (2014). Impact of the spatial and thematic resolution of Holocene anthropogenic land-cover scenarios on modeled soil erosion and sediment delivery rates. The Holocene, 24(1), 67-77.

de Luna, K. M. (2017). Conceptualizing vegetation in the Bantu Expansion: Reflections on linguistics in central African history. Quaternary International, 448, 158-168.

Delneuf, M. (1998). Les recherches archéologiques menées par l'Orstom au Cameroun septentrional. In M. Delneuf, J.-M. Essomba \& A. Froment (Eds.), Paléo-anthropologie en Afrique centrale: Un bilan de l'archéologie au Cameroun. Études Africaines (pp. 91-124). Paris: L'Harmattan.

Déme, A., \& McIntosh, S. K. (2006). Excavations at Walaldé: New light on the settlement of the middle Senegal Valley by iron-using peoples. Journal of African Archaeology, 4(2), 1-32.

Denevan, W. M. (1995). Prehistoric agricultural methods as models for sustainability. Advances in Plant Pathology, 11, 21-43.

Douglass, K., \& Zinke, J. (2015). Forging ahead by land and by sea: Archaeology and paleoclimate reconstruction in Madagascar. African Archaeological Review, 32(2), 267-299.

Eggert, M. K. H., Höhn, A., Kahlheber, S., Meister, C., Neumann, K., \& Schweizer, A. (2006). Pits, graves and grains: Archaeological and archaeobotanical research in southern Cameroun. Journal of African Archaeology, 4(2), 273-298.

Eichhorn, B., \& Neumann, K. (2014). Holocene vegetation change and land use at Ounjougou, Mali. In C. Stevens, S. Nixon, M. A. Murray, \& D. Q. Fuller (Eds.), Archaeology of African plant use (pp. 83-96). Walnut Creek: Left Coast Press.

Ellis, E., Maslin, M., Boivin, N., \& Bauer, A. (2016). Involve social scientists in defining the Anthropocene. Nature, 540(7632), 192-193.

Fairhead, J., \& Leach, M. (1995). False forest history, complicit social analysis: Rethinking some West African environmental narratives. World Development, 23(6), 1023-1035.

Fairhead, J., \& Leach, M. (1996). Misreading the African landscape: Society and ecology in a forestsavanna mosaic. Cambridge: Cambridge University Press.

Fairhead, J., \& Leach, M. (2009). Amazonian dark earths in Africa? In W. I. Woods, W. G. Teixeira, J. Lehmann, C. Steiner, A. Winkler Prins, \& L. Rebellato (Eds.), Amazonian dark earths: Wim Sombroek's vision (pp. 265-278). Dordrecht: Springer.

Fairhead, J., Leach, M., \& Kojo, A. (2012). Anthropogenic dark earths and Africa: A political agronomy of research disjunctures. In J. Sumberg \& J. Thompson (Eds.), Contested agronomy: Agricultural research in a changing world (pp. 64-77). New York: Routledge.

Feinman, G. M. (2015). Settlement and landscape archaeology. In J. D. Wright (Ed.), International encyclopedia of the social and behavioral sciences, 2nd edn (Vol. 21, pp. 654-658). Amsterdam: Elsevier.

Ferro-Vázquez, C., Lang, C., Kaal, J., \& Stump, D. (2017). When is a terrace not a terrace? The importance of understanding landscape evolution in studies of terraced agriculture. Journal of Environmental Management, 202(Pt 3), 500-513.

Fields-Black, E. L. (2008a). Deep roots: Rice farmers in West Africa and the African diaspora. Bloomington: Indiana University Press.

Fields-Black, E. L. (2008b). Untangling the many roots of West African mangrove rice farming: Rice technology in the Rio Nunez region, earliest times to c.1800. The Journal of African History, 49(1), 1-21.

Finucane, B., Manning, K., \& Touré, M. (2008). Late Stone Age subsistence in the Tilemsi Valley, Mali: Stable isotope analysis of human and animal remains from the site of Karkarichinkat Nord (KN05) and Karkarichinkat Sud (KS05). Journal of Anthropological Archaeology, 27(1), 82-92.

Fischer-Kowalski, M., Krausmann, F., \& Pallua, I. (2014). A sociometabolic reading of the Anthropocene: Modes of subsistence, population size and human impact on Earth. The Anthropocene Review, 1(1), 8-33. 
Foley, S. F., Gronenborn, D., Andreae, M. O., Kadereit, J. W., Esper, J., Scholz, D., et al. (2013). The Palaeoanthropocene-The beginnings of anthropogenic environmental change. Anthropocene, 3, 83-88.

Franke, G. (2016). A chronology of the central Nigerian Nok Culture-1500 BC to the beginning of the common era. Journal of African Archaeology, 14(3), 257-289.

Fuller, D. Q. (2007). Contrasting patterns in crop domestication and domestication rates: Recent archaeobotanical insights from the Old World. Annals of Botany, 100(5), 903-924.

Fuller, D. Q., Denham, T., Arroyo-Kalin, M., Lucas, L., Stevens, C. J., Qin, L., et al. (2014). Convergent evolution and parallelism in plant domestication revealed by an expanding archaeological record. Proceedings of the National Academy of Sciences of the United States of America, 111(17), 6147-6152.

Fuller, D. Q., Macdonald, K., \& Vernet, R. (2007). Early domesticated pearl millet in Dhar Nema (Mauritania): Evidence of crop-processing waste as ceramic temper. In R. T. J. Cappers (Ed.), Fields of change: Progress in African archaeobotany. Grongingen Archaeological Studies (Vol. 5, pp. 71-76). Groningen: Barkhuis Publishing.

Fuller, D. Q., \& Stevens, C. J. (2018). Sorghum domestication and diversification: A current archaeobotanical perspective. In A. M. Mercuri, C. D’Andrea, R. Fornaciari, \& A. Höhn (Eds.), Plants and people in the African past: Progress in African archaeobotany (pp. 427-452). New York: Springer.

Gabel, C. (1976). Microlithic occurrences in the Republic of Liberia. West African Journal of Archaeology, 6, 21-35.

Gallais, J. (1967). Le delta intérieur du Niger: Étude de géographie régionale. Dakar: Institut fondamental d'Afrique noire.

Garcin, Y., Deschamps, P., Menot, G., de Saulieu, G., Schefuss, E., Sebag, D., et al. (2018a). Early anthropogenic impact on Western Central African rainforests 2,600 y ago. Proceedings of the National Academy of Sciences of the United States of America, 115(13), 3261-3266.

Garcin, Y., Deschamps, P., Menot, G., de Saulieu, G., Schefuss, E., Sebag, D., et al. (2018b). Reply to Clist et al.: 'Human activity is the most probable trigger of the late Holocene rainforest crisis in Western Central Africa'. Proceedings of the National Academy of Sciences of the United States of America, 115(21), E4735-E4736.

Garcin, Y., Deschamps, P., Menot, G., de Saulieu, G., Schefuss, E., Sebag, D., et al. (2018c). Reply to Giresse et al.: 'No evidence for climate variability during the late Holocene rainforest crisis in Western Central Africa'. Proceedings of the National Academy of Sciences of the United States of America, 115(29), E6674-E6675.

Garcin, Y., Schefuß, E., Schwab, V. F., Garreta, V., Gleixner, G., Vincens, A., et al. (2014). Reconstructing $\mathrm{C}_{3}$ and $\mathrm{C}_{4}$ vegetation cover using $n$-alkane carbon isotope ratios in recent lake sediments from Cameroon, Western Central Africa. Geochimica et Cosmochimica Acta, 142, 482-500.

Garnier, A., Lespez, L., Ozainne, S., Ballouche, A., Mayor, A., Drezen, Y. L., et al. (2015). L'incision généralisée de la vallée du Yamé (Mali) entre 2350 et 1700 ans cal. BP: Quelle signification paléoenvironnementale et archéologique? Quaternaire, 26(1), 49-66.

Giresse, P., Maley, J., Doumenge, C., Philippon, N., Mahe, G., Chepstow-Lusty, A., et al. (2018). Paleoclimatic changes are the most probable causes of the rainforest crises 2,600 y ago in Central Africa. Proceedings of the National Academy of Sciences of the United States of America, 115(29), E6672-E6673.

Glikson, A. (2013). Fire and human evolution: The deep-time blueprints of the Anthropocene. Anthropocene, 3, 89-92.

Grollemund, R., Branford, S., Bostoen, K., Meade, A., Venditti, C., \& Pagel, M. (2015). Bantu expansion shows that habitat alters the route and pace of human dispersals. Proceedings of the National Academy of Sciences of the United States of America, 112(43), 13296-13301.

Gronenborn, D. (1998). Archaeological and ethnohistorical investigations along the southern fringes of Lake Chad, 1993-1996. The African Archaeological Review, 15(4), 225-259.

Gronenborn, D. (2001). Masakwa in the Chad Basin: An examination of the archaeological and historical sources. In S. Kahlheber \& K. Neumann (Eds.), Man and environment in the West African Sahel: An interdisciplinary approach. Berichte des Sonderforschungsbereichs 268 (Vol. 17, pp. 73-84). Frankfurt am Main: SFB 268.

Grove, A. T., \& Sutton, J. E. G. (1989). Agricultural terracing south of the Sahara. Azania: Journal of the British Institute in Eastern Africa, 24(1), 113-122.

Hajdas, I. (2008). Radiocarbon dating and its applications in Quaternary studies. Eiszeitalter und Gegenwart-Quaternary Science Journal, 57(1-2), 2-24. 
Haour, A., Nixon, S., Ndah, D., Magnavita, C., \& Smith, A. L. (2016a). The settlement mound of Birnin Lafiya, Republic of Benin: New evidence from the eastern arc of the Niger River, ca. 4th to 13th centuries AD. Antiquity, 90, 695-710.

Haour, A., Nixon, S., Ndah, D., Magnavita, C., \& Smith, A. L. (2016b). The settlement mound of Birnin Lafiya: New evidence from the eastern arc of the Niger River. Antiquity, 90(351), 695-710.

Harlan, J. R., \& Pasquereau, J. (1969). Décrue agriculture in Mali. Economic Botany, 23(1), 70-74.

Heckenberger, M. J., Christian Russell, J., Toney, J. R., \& Schmidt, M. J. (2007). The legacy of cultural landscapes in the Brazilian Amazon: Implications for biodiversity. Philosophical Transactions of the Royal Society B: Biological Sciences, 362(1478), 197-208.

Hijmans, R. J., Cameron, S. E., Parra, J. L., Jones, P. G., \& Jarvis, A. (2005). Very high resolution interpolated climate surfaces for global land areas. International Journal of Climatology, 25(15), 1965-1978.

Höhn, A. (2007). Where did all the trees go? Changes of the woody vegetation in the Sahel of Burkina Faso during the last 2000 years. In R. Cappers (Ed.), Fields of change: Progress in African archaeobotany (pp. 35-41). Groningen: Barkhuis \& Groningen University Library.

Höhn, A., Franke, G., \& Schmidt, A. (2018). Pits at Pangwari: Charcoal taphonomy at a multi-phased Nok Site, central Nigeria. In A. M. Mercuri, A. C. D’Andrea, R. Fornaciari, \& A. Höhn (Eds.), Plants and people in the African past: Progress in African archaeobotany (pp. 271-299). Berlin: Springer.

Höhn, A., \& Kahlheber, S. (2011). The environment of the Nok sites, central Nigeria: First insights. In 5th International meeting of charcoal analysis: Charcoal as cultural and biological heritage, 2011. SAGVNTVM EXTRA-11 (pp. 153-154).

Höhn, A., \& Neumann, K. (2012). Shifting cultivation and the development of a cultural landscape during the Iron Age (0-1500 AD) in the northern Sahel of Burkina Faso, West Africa: Insights from archaeological charcoal. Quaternary International, 249, 72-83.

Höhn, A., \& Neumann, K. (2016). The palaeovegetation of Janruwa (Nigeria) and its implications for the decline of the Nok Culture. Journal of African Archaeology, 14(3), 331-353.

Holl, A. F. C. (2002). The land of Houlouf: Genesis of a Chadic polity. Ann Arbor: University of Michigan Museum of Anthropology.

Holl, A. F. C. (2009a). Coping with uncertainty: Neolithic life in the Dhar Tichitt-Walata, Mauritania (ca. 4000-2300 BP). Comptes Rendus Geoscience, 341(8-9), 703-712.

Holl, A. F. C. (2009b). Early West African metallurgies: New data and old orthodoxy. Journal of World Prehistory, 22(4), 415-438.

Hubau, W., Van den Bulcke, J., Bostoen, K., Clist, B. O., Smith, A. L., Defoirdt, N., et al. (2014). Archaeological charcoals as archives for firewood preferences and vegetation composition during the late Holocene in the southern Mayumbe, Democratic Republic of the Congo (DRC). Vegetation History and Archaeobotany, 23, 591-606.

Huffman, T. N., \& Schoeman, M. H. (2011). Lebalelo: Early Iron Age pits near Burgersfort, South Africa. The South African Archaeological Bulletin, 66(194), 161-166.

Huysecom, E., Mayor, A., Lorenzo Martinez, M., Aymeric, J., Bocoum, H., Camara, A., et al. (2016). Milieux et techniques dans la Falémé (Sénégal oriental) et sondages au royaume d'Issiny (Côte d'Ivoire): Résultats de la 19ème année du programme «Peuplement humain et paléoenvironnement en Afrique». SLSA Rapport annuel, 109-208.

Huysecom, E., Ozainne, S., Jeanbourquin, C., Mayor, A., Canetti, M., Loukou, S., et al. (2015). Towards a better understanding of sub-Saharan settlement mounds before AD 1400: The tells of Sadia on the Seno Plain (Dogon Country, Mali). Journal of African Archaeology, 13(1), 7-38.

Huysecom, E., Rasse, M., Lespez, L., Neumann, K., Fahmy, A., Ballouche, A., et al. (2009). The emergence of pottery in Africa during the tenth millennium cal BC: New evidence from Ounjougou (Mali). Antiquity, 83(322), 905-917.

Insoll, T. (2002). The archaeologyof post medieval Timbuktu. Sahara, 13(2001-02), 7-23.

Jacobberger, P. A. (1987). Geomorphology of the upper Inland Niger Delta. Journal of Arid Environments, 13, 95-112.

Johnny, M., Karimu, J., \& Richards, P. (1981). Upland and swamp rice farming systems in Sierra Leone: The social context of technological change. Africa, 51(02), 596-620.

Jousse, H., Obermaier, H., Raimbault, M., \& Peters, J. (2008). Late Holocene economic specialisation through aquatic resource exploitation at Kobadi in the Méma, Mali. International Journal of Osteoarchaeology, 18(6), 549-572. 
Jousse, H., Person, A., Finck, A., Albaret, C., Sanogo, K., \& Raimbault, M. (2009). Sites de pêche dans la région du Lac Faguibine à la transition Néolithique-Protohistoire. Afrique: Archéologie et Arts, 5, 119-128.

Junius, H. (2016). Nok early iron production in central Nigeria-New finds and features. Journal of African Archaeology, 14(3), 291-311.

Kahlheber, S. (2004). Perlhirse und Baobab: Archäobotanische Untersuchungen im Norden Burkina Fasos. Johann Wolfgang Goethe-Universität in Frankfurt am Main.

Kahlheber, S., Bostoen, K., \& Neumann, K. (2009a). Early plant cultivation in the Central African rain forest: First millennium BC pearl millet from south Cameroon. Journal of African Archaeology, 7(2), 253-272.

Kahlheber, S., Eggert, M. K. H., Seidensticker, D., \& Wotzka, H.-P. (2014). Pearl millet and other plant remains from the Early Iron Age site of Boso-Njafo (Inner Congo Basin, Democratic Republic of the Congo). African Archaeological Review, 31(3), 479-512.

Kahlheber, S., Höhn, A., \& Rupp, N. (2009b). Archaeobotanical studies at Nok sites: An interim report. Nyame Akuma, 71, 1-17.

Kaplan, J. O., Krumhardt, K. M., Ellis, E. C., Ruddiman, W. F., Lemmen, C., \& Goldewijk, K. K. (2010). Holocene carbon emissions as a result of anthropogenic land cover change. The Holocene, 21(5), $775-791$.

Kaplan, J. O., Krumhardt, K. M., \& Zimmermann, N. E. (2011). The effects of land use and climate change on the carbon cycle of Europe over the past 500 years. Global Change Biology, 18(3), 902-914.

Kaplan, J. O., Pfeiffer, M., Kolen, J. C. A., \& Davis, B. A. S. (2016). Large scale anthropogenic reduction of forest cover in Last Glacial Maximum Europe. PLoS ONE, 11(11), e0166726.

Kay, A. U., \& Kaplan, J. O. (2015). Human subsistence and land use in sub-Saharan Africa, 1000 BC to AD 1500: A review, quantification, and classification. Anthropocene, 9, 14-32.

Kirleis, W., Marinova, E., Valamoti, S. M., Dreibrodt, S., \& Heiss, A. G. (2017). Subsistence strategies in change: The integration of environmental and archaeological evidence on prehistoric land-use. Quaternary International, 436, 1-3.

Klee, M., \& Zach, B. (1999). The exploitation of wild and domesticated food plants at settlement mounds in north-east Nigeria (1800 cal BC to today). In M. van der Veen (Ed.), The exploitation of plant resources in ancient Africa (pp. 81-88). New York: Kluwer Academic/Plenum Publishers.

Klee, M., Zach, B., \& Neumann, K. (2000). Four thousand years of plant exploitation in the Chad Basin of northeast Nigeria I: The archaeobotany of Kursakata. Vegetation History and Archaeobotany, 9 , 223-237.

Klee, M., Zach, B., \& Stika, H. (2004). Four thousand years of plant exploitation in the Lake Chad Basin (Nigeria), part III: Plant impressions in potsherds from the Final Stone Age Gajiganna Culture. Vegetation History and Archaeobotany, 13(2), 131-142.

Lane, P. J. (2015). Early agriculture in sub-Saharan Africa to ca. AD 500. In G. Barker \& C. Goucher (Eds.), Cambridge world history volume II: A world with agriculture (pp. 736-737). Cambridge: Cambridge University Press.

Lang, C., \& Stump, D. (2017). Geoarchaeological evidence for the construction, irrigation, cultivation, and resilience of 15 th-18th century AD terraced landscape at Engaruka, Tanzania. Quaternary Research, 88(3), 382-399.

Lavachery, P. (1998). Le peuplement des Grassfields: Recherches archeologiques dans l'ouest du Cameroun. Afrika Focus, 14(1), 17-36.

Lejju, B. J., Robertshaw, P., \& Taylor, D. (2006). Africa's earliest bananas? Journal of Archaeological Science, 33(1), 102-113.

Lespez, L., Le Drezen, Y., Garnier, A., Rasse, M., Eichhorn, B., Ozainne, S., et al. (2011). High-resolution fluvial records of Holocene environmental changes in the Sahel: the Yamé River at Ounjougou (Mali, West Africa). Quaternary Science Reviews, 30, 737-756.

Levtzion, N., \& Hopkins, J. F. P. (1981). Corpus of early Arabic sources for West African history. Cambridge: Cambridge University Press.

Lewis, S. L., \& Maslin, M. A. (2015). Defining the anthropocene. Nature, 519(7542), 171-180.

Lézine, A.-M., Holl, A. F. C., Lebamba, J., Vincens, A., Assi-Khaudjis, C., Février, L., et al. (2013). Temporal relationship between Holocene human occupation and vegetation change along the northwestern margin of the Central African rainforest. Comptes Rendus Geoscience, 345(7-8), $327-335$. 
Lézine, A.-M., \& McKey, D. (2013). Impact d'une crise environnementale majeure sur les espèces, les populations et les communautés: La fragmentation de la forêt africaine à la fin de l'Holocène. Comptes Rendus Geoscience, 345(7-8), 263-265.

Linares de Sapir, O. (1971). Shell middens of lower Casamance and problems of Diola protohistory. West African Journal of Archaeology, 1, 23-54.

Linseele, V. (2007). Archaeofaunal remains from the past 4000 years in Sahelian West Africa: Domestic livestock, subsistence strategies and environmental changes. BAR International Series 1658. Cambridge Monographs in African Archaeology (Vol. 70). Oxford: Archaeopress.

Linseele, V. (2017). The exploitation of aquatic resources in Holocene West Africa. In U. Albarella, H. Russ, K. Vickers, \& S. Viner-Daniels (Eds.), The Oxford handbook of zooarchaeology. Oxford: Oxford University Press.

Linseele, V., \& Van Neer, W. (2018). Animal exploitation in times of change: Faunal remains from Zilum, ca. 600-400 BCE, north-eastern Nigeria. In N. Rupp, C. Beck, G. Franke \& K. P. Wendt (Eds.), Winds of change: Archaeological contributions in honour of Peter Breunig. Frankfurt Archaeological Studies (Vol. 35, pp. 147-164). Bonn: Habelt-Verlag.

Logan, A. L. (2012). A history of food without history: Food, trade, and environment in west-central Ghana in the second millennium AD. Ann Arbor: University of Michigan.

Logan, A. L., \& D'Andrea, A. C. (2012). Oil palm, arboriculture, and changing subsistence practices during Kintampo times (3600-3200 BP, Ghana). Quaternary International, 249, 63-71.

Lombardo, U., Canal-Beeby, E., Fehr, S., \& Veit, H. (2011). Raised fields in the Bolivian Amazonia: A prehistoric green revolution or a flood risk mitigation strategy? Journal of Archaeological Science, $38,502-512$.

MacDonald, K. C. (1996). The Windé Koroji Complex: Evidence for the peopling of the eastern Inland Niger Delta (2100-500 BC). Préhistoire Anthropologie Méditerranéennes, 5, 147-165.

MacDonald, K. C. (2011). Betwixt Tichitt and the IND: The pottery of the Faita Facies, Tichitt Tradition. Azania: Archaeological Research in Africa, 46(1), 49-69.

MacDonald, K. (2013). Complex societies, urbanism, and trade in the western Sahel. In P. Mitchell \& P. Lane (Eds.), The Oxford handbook of African archaeology (pp. 829-844). Oxford: Oxford University Press.

MacDonald, K. (2014). Invisible pastoralists: An inquiry into the origins of nomadic pastoralism in the West African Sahel. In C. Gosden \& J. Hather (Eds.), The prehistory of food: Appetites for change (pp. 326-341). London: Routledge.

MacDonald, K., Champion, L., \& Manning, K. (2017). Windé Koroji Ouest (Mali, third and second millennia BCE): The environmental and subsistence evidence. In N. Rupp, C. Beck, G. Franke \& K. P. Wendt (Eds.), Winds of change: Archaeological contributions in honour of Peter Breunig. Frankfurt Archaeological Studies (Vol. 35, pp. 165-180). Bonn: Habelt-Verlag.

MacDonald, K., \& Van Neer, W. (1994). Specialised fishing peoples in the later Holocene of the Méma Region (Mali). In W. Van Neer (Ed.), Fish exploitation in the past. Proceedings of the 7th meeting of the ICAZ fish remains working group (pp. 243-251). Tervuren: Royal Belgian Museum for Central Africa.

MacDonald, K. C., Vernet, R., Martinón-Torres, M., \& Fuller, D. Q. (2009). Dhar Néma: From early agriculture to metallurgy in southeastern Mauritania. Azania: Archaeological Research in Africa, 44(1), 3-48.

MacEachern, S. (2012a). The prehistory and early history of the northern Mandara Mountains and surrounding plains. In D. Nicholas (Ed.), Metals in Mandara Mountains society and culture (pp. 27-67). Trenton: Africa World Press.

MacEachern, S. (2012b). Wandala and the DGB sites: Political centralisation and its alternatives north of the Mandara Mountains, Cameroon. Azania: Archaeological Research in Africa, 47(3), 272-287.

MacEachern, S., Djoussou, J.-M. D., \& Janson, R. B. (2010). Research at DGB-1, northern Cameroon, 2008. Nyame Akuma, 73, 37-45.

MacLean, R., \& Insoll, T. (1999). The social context of food technology in Iron Age Gao, Mali. World Archaeology, 31(1), 78-92.

Maggs, T. (1992). Name calling in the Iron Age. The South African Archaeological Bulletin, 47(156), 131.

Magnavita, C. (2002). Recent archaeological finds of domesticated Sorghum bicolor in the Lake Chad region. Nyame Akuma, 57, 14-20.

Magnavita, C., Breunig, P., Ameje, J., \& Posselt, M. (2006). Zilum: A mid-first millennium BC fortified settlement near Lake Chad. Journal of African Archaeology, 4(1), 153-169. 
Maley, J. (2000). Les variations des niveaux du lac Tchad au cours du dernier millénaire: Rôle des conditions climatiques régionales et des apports fluviatiles. Réactions des populations régionales. Comparaison avec le lac Naivasha en Afrique orientale. Mèga-Tchad, 1-2, 21-26.

Maley, J., \& Chepstow-Lusty, A. (2001). Elaeis guineensis Jacq. (oil palm) fluctuations in central Africa during the late Holocene: Climate or human driving forces for this pioneering species? Vegetation History and Archaeobotany, 10, 117-120.

Maley, J., Giresse, P., Doumenge, C., \& Favier, C. (2012). Comment on 'Intensifying weathering and land use in Iron Age Central Africa'. Science, 337(6098), 1040.

Maley, J., \& Vernet, R. (2013). Peuples et évolution climatique en Afrique nord-tropicale, de la fin du Néolithique à l'aube de l'époque moderne. Afriques, 4, 1-51.

Maley, J., \& Vernet, R. (2015). Populations and climatic evolution in north tropical Africa from the end of the Neolithic to the dawn of the modern era. African Archaeological Review, 32(2), 179-232.

Manning, K. M. (2010). A developmental history of West African agriculture. In P. Allsworth-Jones (Ed.), West African Archaeology: New developments, new perspectives. BAR international series (Vol. 2164, pp. 43-52). Oxford: Archaeopress.

Manning, K., \& Fuller, D. (2014). Early millet farmers in the lower Tilemsi Valley, northeastern Mali. In C. J. Stevens, S. Nixon, M. A. Murray, \& D. Q. Fuller (Eds.), Archaeology of African plant use (pp. 73-82). Walnut Creek: Left Coast Press.

Manning, K. M., Pelling, R., Higham, T., Schwenniger, J.-L., \& Fuller, D. Q. (2011). 4500-Year old domesticated pearl millet (Pennisetum glaucum) from the Tilemsi Valley, Mali: New insights into an alternative cereal domestication pathway. Journal of Archaeological Science, 38(2), 312-322.

Maranz, S. (2009). Tree mortality in the African Sahel indicates an anthropogenic ecosystem displaced by climate change. Journal of Biogeography, 36(6), 1181-1193.

Marchant, R., Richer, S., Capitani, C., Courtney-Mustaphi, C., Prendergast, M., Stump, D., et al. (2018). Drivers and trajectories of land cover change in East Africa: Human and environmental interactions from 6000 years ago to present. Earth-Science Reviews, 178, 322-378.

Mayle, F. E., \& Iriarte, J. (2014). Integrated palaeoecology and archaeology-A powerful approach for understanding pre-Columbian Amazonia. Journal of Archaeological Science, 51(C), 54-64.

Mbida, C. M., Van Neer, W., Doutrelepont, H., \& Vrydaghs, L. (2000). Evidence for banana cultivation and animal husbandry during the first millennium BC in the forest of southern Cameroon. Journal of Archaeological Science, 27(2), 151-162.

McDougall, E. A. (1985). The view from Awdaghust: War, trade and social change in the southwestern Sahara, from the eighth to the fifteenth century. The Journal of African History, 26(1), 1-31.

McIntosh, R. J. (1983). Floodplain geomorphology and human occupation of the upper inland delta of the Niger. The Geographical Journal, 149(2), 182-201.

McIntosh, R. J. (1998). The peoples of the middle Niger: The island of gold. Peoples of Africa: Wiley.

McIntosh, S. K. (1999). Floodplains and the development of complex society: Comparative perspectives from the West African semi-arid tropics. Archeological Papers of the American Anthropological Association, 9, 151-165.

McIntosh, S. K. (2001). West African Late Stone Age. In P. Peregrine \& M. Ember (Eds.), Encyclopedia of prehstory (Vol. 1, pp. 319-322). New York: Kluwer.

McIntosh, R. J., \& McIntosh, S. K. (1981). The Inland Niger Delta before the Empire of Mali: Evidence from Jenne-Jeno. The Journal of African History, 22, 1-22.

McWethy, D. B., Whitlock, C., Wilmshurst, J. M., McGlone, M. S., \& Li, X. (2009). Rapid deforestation of South Island, New Zealand, by early Polynesian fires. The Holocene, 19, 883-897.

Meyer, R. S., Choi, J. Y., Sanches, M., Plessis, A., Flowers, J. M., Amas, J., et al. (2016). Domestication history and geographical adaptation inferred from a SNP map of African rice. Nature Genetics, 48(9), 1083-1088.

Mitchell, P. (2013a). Early farming communities of southern and south-Central Africa. In P. Mitchell \& P. Lane (Eds.), The Oxford handbook of African archaeology (pp. 657-670). Oxford: Oxford University Press.

Mitchell, P. (2013b). People and wetlands in Africa. In F. Menotti \& A. O'Sullivan (Eds.), The Oxford handbook of wetland archaeology (pp. 107-120). Oxford: Oxford University Press.

Morin-Rivat, J. (2017). Of trees and men: New insights into man-environment relationships in the moist forests of central Africa during the late Holocene. Ph.D., Université De Liège - Gembloux AgroBio Tech. 
Morin-Rivat, J., Biwole, A., Gorel, A. P., Vleminckx, J., Gillet, J. F., Bourland, N., et al. (2016). High spatial resolution of late-Holocene human activities in the moist forests of central Africa using soil charcoal and charred botanical remains. The Holocene, 26(12), 1954-1967.

Morin-Rivat, J., Fayolle, A., Gillet, J.-F., Bourland, N., Gourlet-Fleury, S., Oslisly, R., et al. (2014). New evidence of human activities during the Holocene in the lowland forests of the northern Congo Basin. Radiocarbon, 56(1), 209-220.

Morrison, K. D., Gaillard, M. J., Madella, M., Whitehouse, N., \& Hammer, E. (2016). Land-use classification. PAGES Magazine, 24(1), 40.

Munson, P. J. (1980). Archaeology and the prehistoric origins of the Ghana Empire. The Journal of African History, 21(4), 457-466.

Murray, S. S. (2007). Identifying African rice domestication in the Middle Niger Delta (Mali). In R. Cappers (Ed.), Fields of change: Progress in African archaeobotany (pp. 53-61). Groningen: Barkhuis \& Groningen University Library.

Murray, S. S. (2008). A report on the charred botanical remains from Sincu Bara, a mid-first millennium AD middle Senegal Valley site. Nyame Akuma, 69, 56-63.

Murray, S. S., \& Déme, A. (2014). Early agro-pastoralism in the middle Senegal Valley: The botanical remains from Waladé. In C. Stevens, S. Nixon, M. A. Murray, \& D. Fuller (Eds.), Archaeology of African plant use (pp. 97-102). Walnut Creek: Left Coast Press.

Murray, S. S., Fuller, D. Q., \& Cappeza, C. (2007). Crop production on the Senegal River in the early first millennium AD: Preliminary archaeobotanical results from Cubalel. In R. Cappers (Ed.), Fields of change: Progress in African archaeobotany (Vol. 5, pp. 63-69). Groningen: Barkhuis \& Groningen University Library.

Mwampamba, T. H., \& Schwartz, M. W. (2011). The effects of cultivation history on forest recovery in fallows in the Eastern Arc Mountain, Tanzania. Forest Ecology and Management, 261(6), 1042-1052.

Netting, R. M. C. (1993). Smallholders, householders: Farm families and the ecology of intensive, sustainable agriculture. Redwood City: Stanford University Press.

Neumann, K., Bostoen, K., Höhn, A., Kahlheber, S., Ngomanda, A., \& Tchiengué, B. (2012a). First farmers in the Central African rainforest: A view from southern Cameroon. Quaternary International, $249(\mathrm{C}), 53-62$.

Neumann, K., Eggert, M. K. H., Oslisly, R., Clist, B., Denham, T., de Maret, P., et al. (2012b). Comment on 'Intensifying weathering and land use in Iron Age Central Africa'. Science, 337(1040), 1040 .

Neumann, K., \& Hildebrand, E. (2009). Early bananas in Africa: The state of the art. Ethnobotany Research Applications, 7, 353-362.

Neumann, K., Kahlheber, S., \& Uebel, D. (1998). Remains of woody plants from Saouga, a medieval west African village. Vegetation History and Archaeobotany, 7, 57-77.

Ngomanda, A., Neumann, K., Schweizer, A., \& Maley, J. (2009). Seasonality change and the third millennium BP rainforest crisis in southern Cameroon (Central Africa). Quaternary Research, 71(3), 307-318.

Niemeijer, D. (1996). The dynamics of African agricultural history: Is it time for a new development paradigm? Development and Change, 27(1), 87-110.

Nixon, S. (2009). Excavating Essouk-Tadmakka (Mali): New archaeological investigations of early Islamic trans-Saharan trade. Azania: Archaeological Research in Africa, 44(2), 217-255.

Nixon, S., Murray, M. A., \& Fuller, D. Q. (2011). Plant use at an early Islamic merchant town in the West African Sahel: The archaeobotany of Essouk-Tadmakka (Mali). Vegetation History and Archaeobotany, 20(3), 223-239.

Norris, K., Asase, A., Collen, B., Gockowksi, J., Mason, J., Phalan, B., et al. (2010). Biodiversity in a forest-agriculture mosaic-The changing face of West African rainforests. Biological Conservation, 143(10), 2341-2350.

Ogundiran, A. (2013). Towns and states of the West African forest belt. In P. Mitchell \& P. Lane (Eds.), The Oxford handbook of African archaeology (pp. 859-873). Oxford: Oxford University Press.

Oslisly, R., Bentaleb, I., Favier, C., Fontugne, M., Gillet, J.-F., \& Morin-Rivat, J. (2013a). West Central African peoples: Survey of radiocarbon dates over the past 5000 years. Radiocarbon, 55(2-3), 1377-1382. 
Oslisly, R., White, L., Bentaleb, I., Favier, C., Fontugne, M., Gillet, J. F., et al. (2013b). Climatic and cultural changes in the west Congo Basin forests over the past 5000 years. Philosophical Transactions of the Royal Society B: Biological Sciences, 368(20120304), 1-10.

Otto, T. (1998). Essai sur l'histoire du paysage au Diamaré pour les deux derniers millénaires. In M. Delneuf, J.-M. Essomba, \& A. Froment (Eds.), Paléo-anthropologie en Afrique centrale: Un bilan de l'archéologie au Cameroun. Études Africaines (pp. 157-164). Paris: L'Harmattan.

Ould Khattar, M. (1995). La fin des temps préhistoriques dans le sud-est Mauritanien. Pantheon-Sorbonne: Université de Paris-I.

Ozainne, S. (2006). Pulsations Sahariennes et premiers cultivateurs: Le Néolithique récent du plateau dogon (3500-500 av. J.-C.). Études Maliennes, 65(Spécial), 69-88.

Ozainne, S., Lespez, L., Garnier, A., Ballouche, A., Neumann, K., Pays, O., et al. (2014). A question of timing: Spatio-temporal structure and mechanisms of early agriculture expansion in West Africa. Journal of Archaeological Science, 50, 359-368.

Ozainne, S., Lespez, L., Le Drezen, Y., Eichhorn, B., Neumann, K., \& Huysecom, E. (2009). Developing a chronology integrating archaeological and environmental data from different contexts: The late Holocene sequence of Ounjougou (Mali). Radiocarbon, 51(2), 457-470.

Park, D. P. (2011). Climate change, human response, and the origins of urbanism at Timbuktu: Archaeological investigations into the prehistoric urbanism of the Timbuktu region on the Niger bend, Mali, West Africa. New Haven: Yale Univeristy.

Patin, E., Siddle, K. J., Laval, G., Quach, H., Harmant, C., Becker, N., et al. (2013). The impact of agricultural emergence on the genetic history of African rainforest hunter-gatherers and agriculturalists. Nature Communications, 5(3163), 1-10.

Pfeiffer, M., Spessa, A., \& Kaplan, J. O. (2013). A model for global biomass burning in preindustrial time: LPJ-LMfire (v.10). Geoscientific Model Development, 6(3), 643-685.

Phelps, L. N., \& Kaplan, J. O. (2017). Land use for animal production in global change studies: Defining and characterizing a framework. Global Change Biology, 23, 4457-4471.

Polet, J. (1995). Première approche d'une industrie sur coquillage identifiée dans un amas coquillier de Basse Côte d'Ivoire (Nyamwan). Journal des africanistes, 65(2), 93-109.

Post Park, D. (2009). Where the camel meets the canoe: Timbuktu's rediscovered past. Past Horizons, 8, 21-25.

Pwiti, G. (1996). Settlement and subsistence of prehistoric farming communities in the mid-Zambezi Valley, Northern Zimbabwe. The South African Archaeological Bulletin, 51(163), 3-6.

Quintana-Murci, L., Quach, H., Harmant, C., Luca, F., Massonnet, B., Patin, E., et al. (2008). Maternal traces of deep common ancestry and asymmetric gene flow between Pygmy hunter-gatherers and Bantu-speaking farmers. Proceedings of the National Academy of Sciences, 105(5), 1596-1601.

Reimer, P. J., Bard, E., Bayliss, A., Beck, J. W., Blackwell, P. G., Ramsey, C. B., et al. (2013). IntCal13 and Marine13 radiocarbon age calibration curves 0-50,000 years cal BP. Radiocarbon, 55(4), 1869-1887.

Robert, D. S. (1970). Les fouilles de Tegdaoust. The Journal of African History, 11(4), 471-493.

Rowold, D. J., Perez-Benedico, D., Stojkovic, O., Garcia-Bertrand, R., \& Herrera, R. J. (2016). On the Bantu expansion. Gene, 593(1), 48-57.

Ruddiman, W. F. (2005). The early anthropogenic hypothesis a year later. Climatic Change, 69, 427-434.

Russell, J., Mccoy, S., Verschuren, D., Bessems, I., \& Huang, Y. (2009). Human impacts, climate change, and aquatic ecosystem response during the past $2000 \mathrm{yr}$ at Lake Wandakara, Uganda. Quaternary Research, 72, 315-324.

Russell, T., Silva, F., \& Steele, J. (2014). Modelling the spread of farming in the Bantu-speaking regions of Africa: An archaeology-based phylogeography. PLoS ONE, 9(1), 1-9.

Salzmann, U., \& Hoelzmann, P. (2005). The Dahomey Gap: An abrupt climatically induced rain forest fragmentation in West Africa during the late Holocene. The Holocene, 15(2), 190-199.

Serneels, V., Eichhorn, B., Kiénon-Kaboré, H. T., N'Zebo, L., Ramseyer, D., Thiombiano-Ilboudo, E., \& Yeo, A. (2015). Origine et développement de la métallurgie du fer au Burkina Faso et en Côte d'Ivoire (5). Prospections et sondages dans la région de Yamane (Burkina Faso) et en recherches à Siola 4000 (Côte d'Ivoire). SLSA Rapport аппиel, 67-102.

Smith, B. D. (2001). Low level food production. Journal of Archaeological Research, 9, 1-43.

Smith, B. D., \& Zeder, M. A. (2013). The onset of the Anthropocene. Anthropocene, 4, 8-13.

Solomon, D., Lehmann, J., Fraser, J. A., Leach, M., Amanor, K., Frausin, V., et al. (2016). Indigenous African soil enrichment as a climate-smart sustainable agriculture alternative. Frontiers in Ecology and the Environment, 14(2), 71-76. 
Sowunmi, M. A. (1999). The significance of the oil palm (Elaeis guineensis Jacq.) in the late Holocene environments of West and West Central Africa: A further consideration. Vegetation History and Archaeobotany, 8, 199-210.

Steier, P., \& Rom, W. (2000). The use of Bayesian statistics for ${ }^{14} \mathrm{C}$ dates of chronologically ordered samples: A critical analysis. Radiocarbon, 42(2), 183-198.

Steier, P., Rom, W., \& Puchegger, S. (2001). New methods and critical aspects in Bayesian mathematics for ${ }^{14} \mathrm{C}$ calibration. Radiocarbon, 43(2A), 373-380.

Stump, D. (2010). Intensification in context: Archaeological approaches to precolonial field systems in eastern and southern Africa. African Studies, 69(2), 255-278.

Tarolli, P., Preti, F., \& Romano, N. (2014). Terraced landscapes: From an old best practice to a potential hazard for soil degradation due to land abandonment. Anthropocene, 6, 10-25.

Uglietti, C., Gabrielli, P., Cooke, C. A., Vallelonga, P., \& Thompson, L. G. (2015). Widespread pollution of the South American atmosphere predates the industrial revolution by $240 \mathrm{y}$. Proceedings of the National Academy of Sciences, 112(8), 2349-2354.

Vanwalleghem, T., Gómez, J. A., Amate, J. I., de Molina, M. G., Vanderlinden, K., Guzmán, G., et al. (2017). Impact of historical land use and soil management change on soil erosion and agricultural sustainability during the Anthropocene. Anthropocene, 17, 13-29.

Vitousek, P. M., Mooney, H. A., Lubchenco, J., \& Melillo, J. M. (1997). Human domination of Earth's ecosystems. Science, 277, 494-499.

Vleminckx, J., Morin-Rivat, J., Biwolé, A. B., Daïnou, K., Gillet, J.-F., Doucet, J.-L., et al. (2014). Soil charcoal to assess the impacts of past human disturbances on tropical forests. PLoS ONE, 9(11), e108121.

Watson, D. J. (2010). Within savanna and forest: A review of the Late Stone Age Kintampo tradition, Ghana. Azania: Archaeological Research in Africa, 45(2), 141-174.

Webb, J. L. A. (1995). Desert frontier: Ecological and economic change along the western Sahel, 16001850. Madison: The University of Wisconsin Press.

White, F. (1983). The vegetation of Africa: A descriptive memoir to accompany the Unesco/AETFAT/ UNSO vegetation map of Africa. Natural resources research (Vol. XX). United Nations Educational, Scientific and Cultural Organization, Paris.

Whitney, B. S., Dickau, R., Mayle, F. E., Walker, J. H., Soto, J. D., \& Iriarte, J. (2014). Pre-Columbian raised-field agriculture and land use in the Bolivian Amazon. The Holocene, 24(2), 231-241.

Widgren, M. (2000). Islands of intensive agriculture in African drylands: Towards an explanatory framework. In G. Barker (Ed.), The archaeology of drylands: Living at the margin (pp. 252-267). London: Routledge.

Widgren, M. (2007). Pre-colonial landesque capital: A global perspective. In A. Hornborg, J. R. McNeill, \& J. M. Alier (Eds.), Rethinking environmental history world-system history and global environmental change (pp. 61-78). Lanham: Rowman Altamira.

Widgren, M. (2010). Besieged palaeonegritics or innovative farmers: Historical political ecology of intensive and terraced agriculture in West Africa and Sudan. African Studies, 69(2), 323-343.

Widgren, M. (2018). Mapping global agricultural history: A map and gazetteer for sub-Saharan Africa, c.1800 AD. In A. M. Mercuri, A. C. D’Andrea, R. Fornaciari, \& A. Höhn (Eds.), Plants and people in the African past: Progress in African archaeobotany (pp. 303-327). Berlin: Springer.

Wotzka, H.-P. (2006). Records of activity: Radiocarbon and the structure of Iron Age settlement in Central Africa. In H.-P. Wotzka (Ed.), Grundlegungen: Beitrage zur europaischen und afrikanischen Archaologie fur Manfred K. H. Eggert (pp. 271-289). Tübingen: Francke.

Wright, D. K. (2017). Humans as agents in the termination of the African Humid Period. Frontiers in Earth Science, 5, 4.

Xing, F., Kettner, A. J., Ashton, A., Giosan, L., Ibáñez, C., \& Kaplan, J. (2014). Fluvial response to climate variations and anthropogenic perturbations for the Ebro River, Spain in the last 4000 years. Science of the Total Environment, 473-474, 20-31.

Yamazaki, D., Ikeshima, D., Tawatari, R., Yamaguchi, T., O’Loughlin, F., Neal, J. C., et al. (2017). A high-accuracy map of global terrain elevations. Geophysical Research Letters, 44(11), 5844-5853.

Zeidler, J., Hanrahan, S., \& Scholes, M. (2002). Land-use intensity affects range condition in arid to semi-arid Namibia. Journal of Arid Environments, 52(3), 389-403.

Publisher's Note Springer Nature remains neutral with regard to jurisdictional claims in published maps and institutional affiliations. 


\section{Affiliations}

Andrea U. Kay ${ }^{1,2}$ (D) Dorian Q. Fuller ${ }^{3,4} \cdot$ Katharina Neumann ${ }^{5}$. Barbara Eichhorn $^{5}$ - Alexa Höhn ${ }^{5}$. Julie Morin-Rivat ${ }^{6}$ - Louis Champion ${ }^{3,7}$. Veerle Linseele ${ }^{8,9} \cdot$ Eric Huysecom $^{10}$. Sylvain Ozainne ${ }^{10} \cdot$ Laurent Lespez $^{11}$. Stefano Biagetti ${ }^{12,13} \cdot$ Marco Madella $^{12,13,14}$. Ulrich Salzmann ${ }^{15}$. Jed O. Kaplan ${ }^{1,16}$

1 Department of Archaeology, Max Planck Institute for the Science of Human History, Jena, Germany

2 School of Social Sciences, University of Queensland, Brisbane, Australia

3 Institute of Archaeology, University College London, London, UK

4 School of Archaeology and Museology, Northwest University, Xi' an 710069, Shaanxi, China

5 Institute of Archaeological Sciences, Goethe-Universität, Frankfurt am Main, Germany

6 Département de biologie, chimie et géographie, Université du Québec à Rimouski, Rimouski, Canada

7 Archaeology Service, Royal Museum for Central Africa, Tervuren, Belgium

8 Ecology, Evolution and Biodiversity Conservation, Katholieke Universiteit Leuven, Leuven, Belgium

9 Royal Belgian Institute of Natural Sciences, Brussels, Belgium

10 Archaeology and Population in Africa Laboratory, Anthropology Unit, Department of Genetics and Evolution, University of Geneva, Geneva, Switzerland

11 Laboratoire de Géographie Physique UMR CNRS 8591, Université de Paris Est-Créteil, Meudon Cedex, France

12 CaSEs - Culture and Socio-Ecological Dynamics Group, UCA/Department of Humanities, Universitat Pompeu Fabra, Barcelona, Spain

13 School of Geography, Archaeology and Environmental Studies, University of the Witwatersrand, Johannesburg, South Africa

14 ICREA, Passeig de Lluís Companys, 23, 08010 Barcelona, Spain

15 Department of Geography and Environmental Sciences, Northumbria University, Newcastle upon Tyne, UK

16 ARVE Research SARL, Pully, Switzerland 